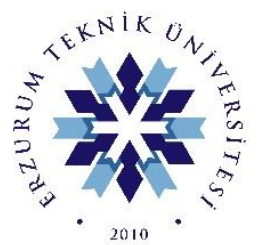

\title{
SİYASİ YÜKÜMLÜLÜK OLMADAN ZIMNİ RIZA
}

\section{TACIT CONSENT WITHOUT POLITICAL OBLIGATION}

\author{
Yazar, JAMES FURNER
}

Çevirmen, YUNUS BADAM

Yüksek Lisans Öğrencisi, Universty of Bahri, Felsefe Bölümü

yubadam@gmail.com

(iD) https://orcid.org/0000000166955700

ETÜ Sosyal Bilimler Enstitüsü Dergisi |ETU Journal of Social Sciences Institute

S.10, Nisan | April 2020, Erzurum

ISSN: 2149-939X

\author{
Makale Türü | Article Types : Çeviri Makale | Translated Article \\ Geliş Tarihi |Received Date $\quad$ : 26.02.2020 \\ Kabul Tarihi | Accepted Date ： 02.04.2020 \\ Sayfa|Pages $\quad: 133-161$ \\ doi : http://dx.doi.org/10.29157/etusbe.135 \\ $\frac{\text { www.etusbe.com }}{\text { https:/ldergipark.org.tr/etusbed }}$
This article was checked by \\ $\checkmark$ iThenticate"
}





\title{
SİYASİ YÜKÜMLÜLÜK OLMADAN ZIMNİ RIZA*
}

\author{
James FURNER \\ Çevirmen: Yunus BADAM \\ ETÜSosyal Bilimler Enstitüsü Dergisi (ETÜSBED), S.10, Nisan 2020, Sayfa: 133-161
}

\section{ÖZ}

'Zımni Rıza', uzun zamandır siyasi düşünceler tarihçilerinin ve siyasal felsefecilerin ilgisini çeken bir konu olmakla beraber, buna dair ince detaylar hala değerlendirilmemiştir. Kökeni Roma hukuk kavramındaki 'Zımni irade beyanına' dayanmaktadır. Bu kavramın açıklanması, 'Zımni rıza beyanı' olarak adlandırdığım yeni bir zımni rıza kavramının belirmesine olanak tanır. Zımni rıza beyanı, hem ortak akla dayanan görüşlerinin önemsizliğini hem de Hobbes'ın beyanındaki zayıflığı önler. Diğer çağdaş felsefi görüşlerin aksine, kurgulardan kaçınır ve niyetliliği yerine getirir. Ayrıca, daha radikal bir eleştiriyi gün yüzüne çıkarırken zımni rıza temelli siyasi yükümlülük teorisinin savunucuları tarafından sunulan iddia türlerinin anlaşılmasına da olanak sağlar. Zımni rıza temelli siyasi yükümlülük teorisi sadece uygulamada sınırlı değil, aynı zamanda savunulamaz niteliktedir.

Anahtar Kelimeler: Locke, Siyasi Yükümlülük, Sessizlik, Zımni Rıza

\section{TACIT CONSENT WITHOUT POLITICAL OBLIGATION}

\section{ABSTRACT}

'Tacit consent' has long interested historians of political thought and political philosophers, but its nuances nevertheless remain unappreciated. It has its roots in the Roman law concept of a 'tacit declaration of will'. Explicating this concept allows a new conception of tacit consent to be proposed, which I term the 'tacit declaration of consent'. The tacit declaration of consent avoids both the triviality of common sense views and a weakness in Hobbes' account. Unlike other contemporary philosophical accounts, it avoids fictions and meets the condition of intentionality. Furthermore, it also advances understanding of the sorts of claim offered by proponents of a tacit consent-based theory of political obligation, whilst facilitating a more radical critique. The tacit consent-based theory of political obligation is not simply limited in application, but indefensible. It unwarrantedly transposes onto tacit consent the potentially fictional character of declarations of will.

Keywords: Locke, Political Obligation, Silence, Tacit Consent

\footnotetext{
* James Furner, Johannesburg Üniversitesi'nde Siyasal Düşünce alanında doktorasını yapmış bir araştırmacıdır. Doktora derecesini Alman-İngiliz ve Amerikan Siyaset Felsefesi alanında Sussex Üniversitesi'nden almıştır. James Furner tarafından kaleme alınan bu makale, Theoria: A Journal of Social and Political Theory, Vol. 57, No. 124 (September 2010), pp. 54-85'te yayımlanmıştır. Yazardan tercüme için izin alınmıştır.
} 


\section{Giriş}

Zımni rıza fikri uzun zamandır devam eden bir tartışma konusu olmuştur. Locke, yazarların yasalara uyma zorunluluğunun sebebini belirli ortak hareketlerin listelenmesi için zımni rıza çağrısında bulunmuş ve bu yasalara uyma zorunluluğunun öneminin büyük bir kısmın 'Hükümet Üzerine İkinci İnceleme' kitabına borçludur. (Locke, 2003: 119). Locke'un üzerindeki geleneksel odağa rağmen, zımni rıza fikri siyasi yükümlülüğü açıklama girişimi ile ilişkilendirilmemelidir. Aslında, kökeni Roma hukukundaki 'zımni irade beyannamesi' kavramına dayanır. Bu kavramı açılamak, entelektüel olarak ikna edici bir zımni rıza ortaya koymaktadır. Aynı zamanda, zımni rıza temelli siyasi yükümlülük beyanının çağdaş destekçilerine daha radikal bir meydan okumaya yol açmaktadır.

Her şeyden önce, çağdaş siyasi felsefede zımni rızanın tartışıldığı olağan bağlamı düşünün. Bu bağlam iki inanç varsayımı ve bir onaylama ile belirlenir: kimsenin, rıza göstermediği sürece yasalara uyma yükümlülügünün olmadığı inancı; siyasal teorinin vatandaşların rıza gösterme koşullarını belirlemeye çalışması gerektiği inancı ve son olarak, çok az sayıda vatandaşın açıkça bu tür bir rızayı kabul gördüğü gerçeğidir. ${ }^{1}$ Rızanın genel olarak verilip verilmediğini gösterirken; bu bağlam, potansiyel bir tehlike içeren zımni rıza fikrine ağır bir yük getirmektedir. Tehlike şudur ki, bir zımni rıza eyleminin eşiği olarak sayılan şeyin, şu anda rızanın temel bir özelliği olarak kabul edilen niyetlilik şartının altına gizlice indirgenmesidir. ${ }^{2}$

Bir an için, 'iradenin zımni beyanı' terimini incelemenin potansiyel kazancı hakkında düşünün. Hukuki bir terim olarak, keskin bir şekilde tanımlanmış kavramlar alanında yer alan çeşitli işlem türlerinde bulunmaktadır. Bu nedenle, sistematik bir düşünce topluluğu içindeki yerini ifade etmek, daha kesin ve ilginç bir zımni rıza kavramının oluşturulmasını kolaylaştırmaya yardımcı olabilir. Bu, F. K. Von Savigny'nin Modem Roma Hukuku Sistemi adlı on dokuzuncu yüzyıl Romen hukukunun meşhur bir Alman dili eserine danışmanın faydalarından biridir. Buna ek olarak, Savigny'nin yerini tekrar tekrar tanımladığı terimlerin, daha az sistematik bir şekilde, Hobbes ve Locke'un çağdaş rıza temelli siyasi yükümlülük hesaplarının başlangıç noktası olarak kabul ettiği pasajlarda olduğunu hayal edin. Bu durumda, Savigny'nin sistemine danışmak da yeni bir sorun ortaya çıkaracaktır.

Siyasi yükümlülüğü açıklamak için müşteriye özel zımni rıza yerine, rıza fikrinin, doğru şekilde detaylandırıldığında, rıza temelli siyasi yükümlülüğün zımni rıza temelli hesaplarını baltalamaya nasıl hizmet ettiği düşünülebilir. Bunlar bu bildirinin ortak amaçlarıdır.

Bildiri, zımni rızaya sahip olanların ortak akla dayanan görüşlerini içeren bir şüpheyle başlar. Zımni rızayı sözsüz yollarla ya da sessiz kalarak rıza göstermek ile 
eşdeğer saymak söz konusu olamaz (bölüm I). Dahası, Hobbes'in çıarım gerektiren işaretlerin rızası olarak zımni rıza beyanı, ortak akla dayanan görüşlerine tatmin edici bir alternatif sunmak için çok karışıktır (II). Savigny'nin Roma hukuku kavramındaki iradenin beyanı görüşü daha sonra açıklanır (III), ve iradenin açık ve zımni beyanları arasındaki ayrım incelenir (IV). İradenin zımni beyanlarının, irade beyanlarının diğer sınıflandırmalarına olan ilişkisini açıklayarak, daha önceki ortak akla dayalı vurgulanan sorunlardan ve Hobbessçu zımni rıza görüşlerinden kaçınılabilir ve zımni beyan kurgudan ayırt edilebilir (V). İrade beyanları ile rıza beyanları arasındaki farklar daha sonra not edilir ve yeni bir zımni rıza anlayışı önerilir (VI). Daha sonra bu anlayışın entelektüel olarak tutarlı olduğunu iddia ediyorum, çünkü niyetlilik durumunu tatmin ediyor, zımni rızaya olan ilgisi, siyasi bağlamda muhtemel istihdamıyla yapılandırılan çağdaş hesaplar değildir, çünkü bu durumu tatmin etme girişimlerinde başarısız olurlar (VII). Son olarak, teorinin genellikle kabul edildiği gibi, yalnızca dar bir şekilde uygulanabilir olmadığını iddia etmeden önce, Locke'un konumunu daha doğru bir şekilde yansitan siyasi yükümlülüğe zımni rıza temelli yaklaşımı yeniden şekillendirmek için bu anlayışın özelliklerini detaylandırıyorum (VIII).

\section{Zımni Rızanın Ortak Akla Dayanan Anlayışı}

Mevcut öneriye en temel itiraz türü, zımni rızayı açılığa kavuşturmak için Romanist bir terim olan 'zımni irade beyanın' kullanmak onu gereksiz olarak kabul etmeyi öngörürdü ki aslında ortak akla dayanan ve bize zımni rızanın karakteri hakkında bilmemiz gereken her şeyi söylüyor.

Ortak akla dayalı yapılan itirazlar aslında iki ayrı zımni rıza görüşünün oluşturulmasına yol açmıştır. Zımni rızanın ortak bir bakış açısı, yakın zamanda Mark Murphy tarafından belirtilmiştir. Murphy şöyle diyor: "zımni" kavramının temel anlamı dil olmadan ifade edilen şey demektir (Murphy, 2006: 98). ${ }^{3}$

Sözlü olmayan rızayla bu zımni rızanın denklemi Jeremy Bentham ve John Austin'e kadar uzanır. Bentham şöyle belirtiyor: "irade şartlı tahliye ifadesi sözcük denilen işaretlerle aktarılandır... İradenin zımni bir ifadesi de, herhangi bir başka işaret tarafından iletilendir" (Bentham, 1977: I, 12, 6-7). Bu arada Austin, Bentham'ın kavram formüllerini komuta hukuk teorisine uyacak şekilde adapte ediyor: "eğer arzu davranışla (ya da kelimeler olmayan herhangi bir arzu işaretiyle) belirtilirse, emir zımnidir "(Austin, 1861: 24). Austin'in hukuk komuta teorisi, zımni komutlar da dâhil olmak üzere, H. L. A. Hart'ın Hukuk Kavramı üzerine klasik çalışmasıyla iyi bilinmektedir (Hart, 1994: 45, 49). Bu çalışmanın odak noktası belki de bu ortak akla dayanan görüşünü benimseyen Locke'a tabii olan veya olmayan yorumcu sayısının hesaplanmasına yardımcı olur. John Bennett şöyle ifade eder: 'zımni rıza en basit haliyle kelimeler olmadan verilen rizadır' (Bennett, 1979: 227). Paul Russell onu doğrular nitelikte: "Locke'un rızadan kastı sözlü rızadır" (Russell, 1986: 295) ${ }^{4}$ 
A. J. Simmons tarafından zımni rızanın ikinci bir ortak akla dayanan görüşü (sadece ilk aşamada) önerilmektedir. Simmons şöyle diyor: "sessiz ve pasif kalındığı takdirde rıza zımni olarak adlandırılır" (Simmons, 1979: 80). ${ }^{5}$ Aynı şekilde Plamenatz; 'zımni rıza', ağız sözüyle ifade edilemez, ne yazılı olarak, ne de başka bir eylemle değil, aksine eylemsizlikle ifade edilir' (Plamenatz, 1968: 8). Zımni rızanın bu ikinci ortak akla dayanan görüşü ilkinden daha kısıtlayıcıdır. Zımni rızayı, sabit ve sessiz kalmayı içeren sözlü olmayan rıza eylemlerine indirger.

Şimdi, eğer zımni rızanın bu iki ortak akla dayanan görüşünden biri tatmin ediciyse, zımni rızanın zımni karakteri hakkında daha teknik bir tartışmaya gerek yoktur. Bu nedenle, ilk meydan okuma, Roma hukuku kavramindan ilham alan bir teknik tanımın savunucuları için, zımni bir irade beyanının ortak akla dayanan görüşlerinin yetersiz olduğunu iddia etmektir. Zımni rızanın ortak akla dayanan görüşlerinin ötesine geçmek için gerekli motivasyon, tamamen kendileri için önemsiz olmalarıdır. Oldukça açık ki, insanlar bedensiz sesler değildir. Çeşitli yollarla hareket edebilir ve rıza gösterebilirler. Bazı yollar diğerlerinden daha az belirsiz, bazıları diğerlerinden daha geleneksel olabilir. Ancak, belirli bir eylem türüyle belirli bir yasal sonucun ortaya çıkması sosyolojik olarak ilgi çekici olsa da (örneğin, bir kızın sessizliğinin bir kez onun nişanı için yeterli olduğunu), rızanın çeşitli yollarla işaret edilebileceği genel durum, genel yasal veya felsefi bir çıkar değildir. Yasada, rızanın iletildiği biçimin, sınırlandırılma derecesi ile genel bir ilişkisi yoktur.

Sözlü olmayan riza eylemleri, bir kişiyi sözel eşdeğerlerinden daha fazla veya daha az bağlamaz. Ayrıca, rızanın iletildiği form, rızanın ne olduğu veya ne tür düzenlemeleri haklı çıkardığına dair felsefi tartışmalarda hiçbir rol oynamaz.

Mesele, ortak akla dayanan rıza eylemlerinin ayırt edilebileceği yolları önerme yeteneği konusunda şüphe uyandırmak değildir. Aksine, sürdürdüğü tipolojiler teorik olarak ilgi çekici değildir.

Elbette, önemsiz olmayan iddiaların, zımni rızaya dair yukarıda belirtilen ortak akla dayanan görüşlerinden birine itiraz ile ileri sürülebileceği kabul edilmelidir. Ancak buradaki cevap, bu tür iddiaların, sahip oldukları yasal veya felsefi ithalatın oldukça bağımsız bir ayrıma borçlu olmasıdır.

İlk örnekleme olarak, belirli bir yasal işlemin ancak belirli bir biçim alırsa geçerli olduğunu belirten bir yasal kural olduğunu düşünün. Böyle bir kural nedeniyle, öngörülen formu gözlemlemeyen rıza eylemleri yasal olarak hiç bağlayıcı olmayabilir. Şimdi, zımni rızanın ortak akla dayanan görüşleri, açık ve zımni rıza arasındaki çizgiyi çizebilir, böylece bu ayrım, yasal olarak geçerli olmayanlardan yasal olarak geçerli olan rıza eylemlerini ayıran sınır çizgisine denk gelir. Eğer öyle olsaydı, zımni rızanın bağlanmadığı önemsiz ve gerçek olmayan ifadeyi yapmak için zımni rızanın ortak akla dayanan görüşü kullanılabilirdi. Ancak bu tesadüfi 
senaryo sadece bu tür görüşlerin genel analiz için uygun olmadığını göstermektedir. Daha genel olarak kullanıldığında, bu görüşler rızanın verildiği forma yanlış ya da ayırt edilmeyecek bir şekilde dikkat çekecektir. Burada gerekli olan genel ayrım, bağlayıcı olmak için yasal olarak öngörülen bir prosedüre uyması gereken rıza eylemleri ile iletilen her türlü biçimde yasal olarak bağlayıcı olabilecek rıza eylemleri arasında yapılmalıdır. Bunun için, zımni/açık ayrımın ortak akla dayanan görüşlerinin bir faydası yoktur.

İkinci bir vaka türü, Simmons'un aşağıdaki senaryo hakkındaki yorumu ile gösterilmiştir:

Düşünün: Başkan Jones, şirketin yönetim kurulu toplantısının kapanışında duyuruyor, "Kurulun, perşembe günkü saatimizden ziyade salı günü saat 8:00'de katılımın zorunlu tutulacağı bir toplantı yapılacak. Herhangi bir itirazı olan var mı?" Yönetim kurulu üyeleri sessiz kalıyor. Sessiz ve hareketsiz kalarak, başkanın program değişikliği yapma önerisine zımnen razı oldular (elbette, üyelerin hiçbirinin uyumadığını veya duymadıklarını varsayarak vb.). Sonuç olarak, Başkan'a toplantıyı yeniden planlamak için (normalde sahip olmadığı) hakkı verdiler ve yeni zamanda katılma yükümlülüğünü üstlendiler. (Simmons, 1979: 79-80). ${ }^{6}$

Buradaki en önemli sorun, yönetim kurulu üyelerinin onay vermeleri gereken çelişkili önerilerdir. Başkanın normalde bu hakka sahip olmadığ şeklindeki ima ile 'yeni zamanda katılmak' için onay vermeleri ya da zorunlu yönetim kurulu toplantılarını yeniden düzenlemek için hakkı' devretmeleri gerekiyor mu? Cevap her ikisi de olamaz. Zorunlu yönetim kurulu toplantılarına katılmak, yönetim kurulu üyeliğinin görevlerinden biridir. Uygun prosedürlere göre bir tarih değişikliği yapılırsa, görevlerinin bir parçası olarak yeniden planlanan zamanda katılmak, Yönetim Kurulu üyelerinin görevidir. Başkanlarının zorunlu toplantıları yeniden planlama ve yeniden düzenleme hakkı varsa, Yönetim Kurulu üyeleri yeni zamanda katılmakla yükümlüdürler. Kendileri için herhangi bir rıza işlemi gerekmez. Gerçekten de, Yönetim Kurulu üyeleri başkanlarına yeniden planlama hakkını vermeye razı olursa, bu konuda şüphe duymazlar ve bu nedenle, bu rızanın uygunsuz olduğunu bildikleri için, katılmalarına izin veremezlerdi. Bu nedenle, burada mümkün olan tek rıza, Yönetim Kurulu üyelerinin zorunlu Yönetim Kurulu toplantılarını yeniden düzenleme hakkını devretme rızasıdır. Bu açılamanın yapılması için gereken genel ayrım, bireylerin özel bir ilişki ışı̆̆ında (örneğin, işte) görevlerini yerine getirme durumları ile özel görevlerin olmadığı durumlar arasında (örneğin, sokaktaki insanlar arasında) olmalıdır. ${ }^{7}$ Açık ve zımni rıza arasındaki ortak akla dayanan ayrımları ile özel görevlerin birbirine karıştırılması sadece konuyu karıştırır. 
Üçüncü bir dava türü, katılımcılara belirli soru türlerine cevap olarak kendilerini beyan etme konusunda özel bir görev verilmesi durumunda özel ilişkiler ortaya çıktığında belirir. Örneğin, bir başkan ile aynı Kurulun diğer üyeleri arasındaki özel ilişkinin bir özelliği, bu önerilerin Yönetim Kurulu üyeleri olarak görevleriyle ilişkili olması ve uygun kanallar aracılığıyla yükseltilmesi koşuluyla, Yönetim Kurulu üyelerinin Başkan önerilerine cevap verme görevine sahip olmalarıdır. Biri bunu tamamen makul kabul edebilir ve yine de, kişisel özgürlük temelinde, yoldan geçenlerin, mallarını satın almalarını teklif eden bir sokak satıcısının davetsiz gelişmelerine cevap verme yükümlülüğünün bulunmadığını doğrulayabilir. (Gross \& Söhnlein, 1993: 45). Savigny'nin belirttiği gibi burada gerekli olan genel ayrım; bir başkasının 'hakkını' kabul etmediğimde olumlu bir çelişki yaratmaya çalışmaktır '(Savigny, 1841: 132) ve diğerlerinin böyle bir hakkı olmadığı senaryoları arasında yer alan özel ilişki türleri arasındaki ayrımdır. ${ }^{8}$ Bu konuda açık ve zımni rıza arasında ortak bir duyu ayrımının yapılması yararsızdır. ${ }^{9}$

Sessizlik, beyan etme görevinin yokluğunda rıza gösterebilir, beyan etme görevi ise sessizliği bağlayıcı hale getirir, ancak yükümlü olarak rıza göstermez. Şu anda, zımni rızanın ortak akla dayanan tanımları kullanılarak söylenen ve genel ilgi alanı olan herhangi bir şey, bu tanımlamalar olmadan daha fazla hassasiyet ve daha az kafa karışıklığı ile söylenebilir.

\section{II. Çıkarımla Rıza Olarak Zımni Rıza}

Zımni rızanın ortak akla dayanan kavramlarının içsel önemsizliği, zımni rızanın ne olduğuna dair daha sofistike bir teorik bakış açısına duyulan ihtiyacı vurgular. Savigny'in irade beyanına ilişkin ifadesinden daha yakın olan, zımni rıza görüşlerine dair teorik bir alternatiften, bazen Hobbes'un sözleşmeye bağlı işaret türleri arasındaki ayrımından çıkarılabilir olduğu düşünülmektedir (Murphy, 1994: 85). Hobbes şöyle ifade ediyor:

"Sözleşme işaretleri ya açık ya da çıarım yoluyladır. İfade denilen şey, işaret edilen veya belirtilen şeyi anlamakla konuşulan kelimelerdir; ... Çıkarımla işaretler bazen kelimelerin sonucudur, bazen sessizliğin sonucu, bazen eylemlerin sonucu, bazen bir eylemden vazgeçmenin bir sonucudur ve genellikle herhangi bir sözleşmenin çıkarımıyla ilgili bir işaret, yüklenicinin iradesini yeterince belli eder niteliktedir (Hobbes, 1998: 14, 13 14)".

Sözleşme hesabından bir onay hesabı geliştirmek tehlikelidir. Yine de, Hobbes'in sözleşmeli 'çıkarımla işaretler' hesabı, 'Yüklenicinin iradesi' olarak atıfta bulunduğu sürece, gerçek bir niyeti belirtmek için zımni bir rıza hesabı geliştirmek için kullanılabilir. Bu yorumda Hobbes, sözel ifadelerin 'sonucu' olarak çıkarımla işaretleri tanımladığında veya özellikle akılda sonuçları amaçladığında, bu nitelik, yasal sonuçları olan kasıtlı eylemler ile yasal sonuçları amaçlanan kasıtlı eylemler 
arasında ayrım yapma ihtiyacına işaret eder. 'İrade beyanı' teriminin incelenmesi bu konuda yardımcı olur. Ancak burada vurgulanması gereken ayrı bir sorun var. Çıkarım gerektiren işaretlerin rızası olarak zımni rızayı görüntülemeyle ilgili asıl sorun, 'çıkarım işaretleri'nin önemli bir ayrımı karıştırmasıdır. Her ikisi de işlev türünden birbiriyle çok farklı olmasına rağmen çıkarım ışığında rıza belirtileri sağlamak için sözlü veya sözel olmayan eylemlerin yapılabileceği gerçeğini gizler. Tek bir işlev, tek bir yükümlülüğü üstlenmek anlamına gelen bir eylemin koşullarını netleştirmek için çıkarımın kullanılmasından ibarettir. Örneğin bir sözleşmeye girme niyeti ile tartışmasız yapılan sözlü veya sözlü olmayan eylemler yine de belirsiz, karışık veya muğlak bırakabilir.

Birkaç elmayı işaret ederken, ya da 'bu elmaları bir Avro için alabilirsin' diyerek bile, hangi elmanın teklif edildiğine ya da kaç elmanın sunulduğu konusunda belirsizlik olabilir ve kesin türlerini veya sayılarını belirlemek için bir tür çıkarım için çağrı yapabilir. Ancak, 'çıkarımla işaretler' kategorisi, çıkarımlar ışığında çok farklı bir işlevle rıza işaretleri sağlamak için yapılan sözel veya sözel olmayan eylemleri de kapsar. Çıkarımlar, zaten kesin bir yasal veya ahlaki anlamı olan bir eylemin, bir çıkarımın başlangıç noktası olarak hizmet ettiği zaman, ikinci bir işleve hizmet eder. Bu durumlarda, çıkarımın işlevi, bir eylemin ikinci yasal veya ikinci ahlaki anlamını sağlayan bir yükümlülüğün üstlenilmesini ortaya çıkarmaktır. IV. bölümde, Savigny'nin Roma medeni hukukunda tanımladığı örnekleri, hâlihazırda kurulmuş bir yasal anlamı olan eylemlerin, ayrı bir yasal yükümlülüğün üstlenilmesini ortaya çıkarmanın bir nedeninin olduğunu ve eylemi iki kat yasal önemle sağlamanın başlangıç noktası için sağladığı örnekleri sunuyorum. Burada, Locke tarafından gündeme getirilen bir durumu düşünmek yeterli olabilir. Locke'a göre, 'şimdi oturduğum evde kalmak için iki yüz euro ödemeyi kabul ediyorum, bu geceden başlayarak bir haftalığına' kabul ediyorum gibi bir ifade yasaya uyma onayının 'çıkarım işareti' olarak hizmet edecektir. ${ }^{10}$ İşte Hobbes'un kategorisi, tam da bu iki tür vakayı bir araya getiriyor.

Hobbes'un savunmasında, İkinci tür işlevi olan çıkarımlarla hiçbir zaman karşılaşmadığı için Hobbes'in kafasının karışmamış olması öngörülebilir. Ancak bununla birlikte, kavramsal açıklık, farklılıkları sessizce asimile eden terimlerle sunulmaz. Zımni rızanın doğası, iki farklı çıkarım işlevinin birbirine sessizce asimile edilmesine izin vererek açılığa kavuşturulmaz. "Çıkarım yoluyla" rıza belirtileri kategorisi, birbirinden oldukça farklı iki eylem türünü bir arada gruplamak için kullanılabildiğinden, üzerinde zımni bir rıza hesabı oluşturmak için çok karışık bir kategori kullanılmaktadır. Bu iki farklı işlev türünü üstlenme çıkarımı olasılığını teorik olarak yapabilen bir hesap incelemenin zamanı geldi. 


\section{III. İrade Beyanı}

Daha az bilinen ancak kavramsal olarak zımni rıza göstermenin daha sağlam bir yolu, Savigny'nin Sisteminin üçüncü cildindeki "irade beyanı [Willenserklärung] "konusundaki tartışmasını incelemektir. Stefan Riesenfeld haklı olarak bu çalışmayı "Savigny'nin özel hukuk yapı taşlarının tanımlanmasında kalıcı katkı veren çalışmalardan biri" olarak adlandırdı (Riesenfeld, 1989: 3). Bu terim çağdaş Alman hukuk ekolünün merkezinde kalır.

İrade beyanı, kişilerin haklarını ve görevlerini belirli bir tür eylemden dolayı değiştiren bir tür yasal gerçektir. Bu iki bileşen açısından analiz edilebilir: 'iradenin kendisi' ve 'iradenin beyanı' (Savigny, 1841: 114). İlk bileşen olan, "iradenin kendisi", düşünülebilecek birkaç karardan bir seçenek olarak, değişik şekillerde hareket etme kararıdır (Savigny, 1841: 114).

Daha açlk bir ifadeyle, irade, 'belki de sadece yasal olmayan amaçlara bile yol açsa bile, yasal ilişkinin başlamasına veya sonlandırılmasına yönelik olmalıdır' (Savigny, 1841: 104). Bu iradeyi açıklamak gerekirse, artan karmaşıklık sırasına göre, bir kararın ürünü olabilecek veya olamayacak hareketleri; yazarları için yasal sonuçları olabilecek veya olmayacak olan kasıtlı eylemleri ayırt etmeye yardımcı olur.

En basit haliyle, bazı hareketler kasıtlı, diğerleri değildir. İmzalanmış bir sözleşmenin fiziksel eyleminin bile kasıtlı olması gerekmez. Aynı bedensel hareket, bir davetsiz misafirin uyuyan birinin eline bir kalem yerleştirmesi ve elini sözleşmeli bir belge üzerinde yönlendirmesi durumunda ortaya çıkabilir (Savigny, 1841: 114, 134). Bu tür hareketler bir irade beyanı teşkil etmez, çünkü ikincisi kasıtlı bir eylemdir.

İkinci olarak, bazı kasıtlı eylemler yazarları için yasal sonuçlar doğururken, diğerleri bunu yapmaz. Eylemlerin yasal sonuçları olsa bile, yalnızca bunları gerçekleştirenler dışındaki kişilerin haklarını ve/veya görevlerini değiştirebilirler. Savigny, 'özgür eylemler' yapan kişiler için yasal sonuçları olan kasıtlı eylemleri şart koşar (Savigny, 1841: 104)

Üçüncü olarak, kasıtlı bir eylem gerçekleştirerek kişilerin maruz kaldığı bazı yasal sonuçlar, başkalarının yapmadığı halde, yasayı yasal haklarını ve/veya görevlerini değiştirme niyetinde olmalarını gerektirir. Sözleşmeler, ikincisinin bir türü olan (Savigny, 1841: 104) 'işgal yoluyla mülkiyet' edinimi ${ }^{11}$ olan bir türdür, örneğin vahşi hayvanların avcılar tarafından işgali gibi. Avcılar, hayvanlar üzerinde tevkif ve sahip olma istekleri olduğu sürece mülk edinirler. Bunun dışında mülkiyet hakları elde etmek niyetinde olamazlar: 'mülk edinme konusunda özel bir irade öngörülmemektedir' (K.-H. Gursky et al. 2004: 958, 5). Aynı şekilde, hirsızlık yapanlar, bu tür eylemlerin yasal sonuçlarından haberdar olsalar bile, bu eylemlerin tabi olduğu yasal sonuçları düşünmezler. (Savigny, 1841: 104) İrade beyanının 
gönüllü bileşeni, birinin yasal haklarını ve/veya görevlerini değiştirme niyetidir. Bununla birlikte, eşlik eden sebep önemsizdir ve satın alınan bir ürünün kullanımı gibi 'yasal' olmayabilir. İrade beyanlarının ikinci bileşeni olan beyanname, 'görünen dünyada bir sudur olarak' iradenin varlığıdır (Savigny, 1 841: 130). Savigny şöyle diyor: 'sadece içsel, görünmez bir olay olduğu için başkalarının tanıyabileceği bir işarete ihtiyaç duyan iradenin kendisi tek önem ve etki olarak düşünülmelidir'.

Beyanname, iradenin açığa vurulduğunun işaretidir '(Savigny, 1841: 134). Kişinin yasal haklarını ve/veya görevlerini değiştirildiğine dair bir işaret gereklidir, çünkü bir işaret olmadan (sözel veya sözel olmayan, pozitif aktif veya ihmal olsun), diğerleri bunun verildiğini bilmedikleri için sadece bir kişinin izniyle hareket edemezler. Ancak irade beyanlarının istemli yönü yine de son derece önemli ve etkilidir. Ve beyanın geçerliliğinin tek temelini oluşturur. Yasal sonuçların ortaya çıkması için bir deklarasyon gerekebilir, ancak bunları deklarasyona bağlamayı haklı kılan bir niyetin varlığıdır.

\section{Zımni İrade Beyanı}

Savigny'nin beyanına göre, irade beyanı kişinin yasal haklarını ve/veya görevlerini değiştirme niyetinin bir işaretidir ve açık veya zımni olabilir. Bu ayrımı şöyle açıklıyor:

İradenin kendisi, içsel bir gerçek olarak, sadece dolaylı olarak ve makul bir şekilde algılanabilir bir gerçek ile bilinebilir. Bu bilgi aracı iki çeşit olabilir. Genellikle, sadece bir irade işareti olarak hizmet etmenin tek sorumluluğuna sahiptir; ancak yine de iradenin ifadesini içerecek [selbständige Bestimmung]; şekilde bağımsız kararlılığa sahiptir. İlk durumda, irade beyanı açık olarak adlandırılır [ausdrücklich]; ikinci durumda ise zımni olarak [stillschweigend] (Savigny, 1841: 131).

Bir irade beyanı, yalnızca 'iradenin işareti olarak' hizmet eden bir eylem tarafından sağlanırsa, bu durumda kişinin yasal haklarına ve/veya görevlerine tek bir değişiklik yapma niyetini işaret etmekten başka yasal bir önemi yoktur. Örneğin, bir sözleşmeyi imzalamak, yasal olarak bağlayıcı bir sözleşme yapma niyetini belirtmekten başka hiçbir yasal öneme sahip değildir. Öte yandan, daha belirgin bir 'bağımsız kararlılık' veya sonuç veren bir eylem tarafından bir irade beyanı sağlanırsa, bu beyan 'zımni' olur. Ancak birincil sonuç da yasal olmalıdır. Hiçbir irade beyanı, herhangi bir yasadışı sonuç vermeden gerçekleşmez ve bir kanunun yasal ve yasadışı boyutlarını hükmetmek yasal bir çıkar oluşturmayabilir. İradenin zımni beyanlarını sağlayan eylemler böylece iki kat yasal öneme sahip olurlar. ${ }^{12}$

Bu tür işlemlerin yasal olarak önemi, zımni beyan ve birincil sonuçlarının nasıl ilişkili olduğu sorusunu gündeme getirmesidir. Ancak Savigny, bu soruya verilen kısa cevaplarla noktayı koydu. Sadece Roma medeni hukukunda belgelenen bazı davalara işaret ediyor: 
(1) Eğer bir mirasın düştüğü kişi mülkün işlerini yönetirse, o zaman, kural olarak, bu 'pro hedere gestio' aracılığılla, o kalıtım içine girer. Bununla birlikte, böyle bir eylemin yorumu, açık bir karşı bildirimde, hatada veya kanıtlanmış diğer niyetlerle reddedilebilir. (2) Ehliyetsiz davalar zımni bir uzatma olarak sayılmadan önce gönüllü olarak davada yer almak, davalarda görünmenin yargı yetkisi ile ilgili bir hata ile hariç tutulmasına rağmen, zımni bir uzatma olarak sayılır. (3) Kim, kendi başına başkalarının komisyonsuz olarak yaptıkları bir davaya devam ederse, böyle bir durumda diğerinin önceki usul müzakerelerini onaylamış olur. (4) Eğer bir alacaklı gelecek bir dönem için faiz kabul ederse, bu sürenin bitiminden önce sermayeyi talep etmeyeceği sözünü verir. (5) Biri sözleşmede olmayan bir şey vaadinde bulunursa ve mal sahibi teminat belgesini imzalarsa, teminat için zımni bir anlaşma yapılır. (6) eğer bir müşterek mirasçı, miras alınan tüm arazileri satarsa ve kalan müşterek mirasçılar da anlaşarak, satıştan elde edilen paranın paylarını da kabul ederlerse, paylarının zımni satıcıları olarak kabul edileceklerdir. (Savigny, 1841: 131, numaralandırma eklendi).

$\mathrm{Bu}$ örneklerdeki eylemlerin hepsinin aynı ilişki türünü gösterdiğini iddia ediyorum; yani, iradenin zımni beyanı birincil sonuç ile yasal zemin sağlamaya yardımcı olur. Bu iddiayı desteklemek için (4) ve (6) örnekleri göz önünde bulundurabiliriz. Bu iki örneği anlamak için, Roma hukuku ve modern Alman hukuku gibi bazı hukuk sistemlerinin, mülkiyetteki değişikliklerin birden fazla işlemin tamamlanmasını gerektirmesini sağlayan bir ayrılık ilkesini benimsediğini tanımak önemlidir. ${ }^{13}$ Satış sözleşmesi olan bir işlem, içeriği sözleşmede olan iki irade beyanından oluşur.

Örnek olarak A: 'Bu gazeteyi bir euro karşılığında satın almak istiyorum' diyerek B'ye bir teklifte bulunur ve B: 'Bu gazeteyi bir euro karş1lı̆̆ında satmak istiyorum' diyerek kabul eder. Bu işlemin sonucu, her iki tarafın da mülkiyet haklarını kendi kalemlerine devretme yükümlülüğü getirmesidir. Bununla birlikte, her bir malın devri, malın fiziksel olarak tesliminin yanı sıra, A ve B'nin mülkiyet devri ile ilgili vasiyetname beyannameleri arasındaki ilave anlaşmadan oluşan ayrı bir işlemdir. Her iki transferinde sonucu, A ve B'nin her birinin, diğerinin eski mülkiyeti olan bir eşyaya sahip olma hakkına sahip olmasıdır.

Şimdi, ayrılma ilkesi, mülkün el değiştirmesi için iki ayrı yasal işlem türünün gerekli olduğunu belirlerken, her iki işlem türüne ait irade beyanları yine de bir ve aynı eylemde gerçekleştirilebilir (Brüt \& Söhnlein, 1993: 49; Martinek, 2004: 433ff, 88). Kararlaştırıldığı gibi mal alma kanunu ayrıca bir satış sözleşmesi sonuçlandırmak için zımni bir beyanda bulunabilir. Günlük bir senaryoyu almak 
gerekirse, satış sözleşmesinin teklifi, insanlı bir kiosk'dan geçen, masaya bir euro koyan ve bir gazete alan biri tarafından açıkça ilan edilebilir. Benzer bir hikâye Savigny'in bir satıştan faiz veya para kabulü ile ilgili örnekleri için de geçerlidir. Kanunun doğrudan hukuki sonucu, yasal bir devri tamamlamaktır, ancak yasa ayrıca bunun dışında bir sözleşme imzalama isteğini ilan etmeyi de sağlar. En önemlisi, devir ve sözleşme arasında sıkı bir ilişki var. Sözleşme geçerli olduğu takdirde devir güvenlidir. Bu nedenle, (4) ve (6) durumlarında zımni beyanname, birincil işlemin sonucu için yasal bir zemin oluşturan bir işleme aittir. Zımni beyan ve birincil sonuç arasındaki benzer bir ilişki, kalan örneklerin her birini karakterize eder. Örnek (1) ele alalım: 'eğer bir mirasın düştüğü kişi mülkündeki işleri yönetirse, zımni bir mirasa girmiş olur'. Bir mülkün işlerini yönetme eylemi, bunun yanında, bir mirasa girme kararını işaret etmek için hizmet edebilir, böylece ikincisi mülkle uğraşmanın yasal zeminini sağlar. Ya da (2)'yi göz önüne alalım, ehliyetsiz bir dava da yapılan işlemlerde gönüllü olarak katılma, zımni bir protesto olarak sayıldığı durumları düşünün. Mahkemede görünme eyleminin birincil hukuki sonucu bir dava yürütmektir; ancak mahkemede görünme eylemi, bunun yanı sıra, ehliyetsiz bir yargıcın yargı yetkisini genişletmek için de hizmet edebilir ve böyle bir durumda, zımni beyan, kanunun birincil sonucuna yasal zemin sağlamış olur. Örnek (3)'te, kendisi tarafından bir başkasının komisyonsuz yaptığı bir davayı sürdüren' davacı, kendi nezaketinde kendi davalarını yürütme rolünü üstlenecek bir eylem gerçekleştirmiştir. Ancak, eski vekilin davacı tarafından onaylanmamış olması halinde, bu işlem, vekilin kendi adına yaptıkları önceki eylemleri zımni bir şekilde doğrulamasına hizmet edebilir; ve bu teyit olmadan dava devam edemez. Son olarak, örnek (4): Biri sözleşmede olmayan bir şey vaadinde bulunursa ve mal sahibi teminat belgesini imzalarsa, teminat için zımni bir anlaşma yapılır. Bir teminat belgesi imzalamanın ilk yasal sonucu, iki taraf arasındaki bir tanığın varlığıdır. Burada, tanığın temin verilen malın sahibi 'olduğu durumlarda, teminat belgesinin imzalanması aynı zamanda rehinle yapılan anlaşmanın kesin bir beyanı olarak da kabul görülebilir; ve mal sahibinin onayı olmadan, teminat sahibine tanıklık etmek yasal bir dayanaktan yoksundur. (Buradaki sahte zımni beyanın sözlü bir şekilde yapıldığını unutmayın.) Zımni beyanname ve birincil sonuç arasındaki önerilen ilişki bu nedenle bu gibi çeşitli davalarda daha genel olarak ele alınır. Zımni beyan, yasal yükümlülüğe karşı savunmasızlığını açığa çıkararak, eylemin birincil sonucunu yasal bir zemin ile destekler (veya başka bir işlemin bir parçası haline getirir).

Zımni beyan ile birincil sonuç arasındaki ilişkinin bu tanımını desteklemek için, alternatif bir yorum getirmek istiyorum. Zımni beyan, birincil sonuç kanıtında gerekli bir bileşen olarak düşünülmemelidir, ya da başka bir şekilde, bir zımni beyanın performansını belirtmek için ikincisinin kanıtı olarak kullanılmamalıdır. $\mathrm{Bu}$ yorumu göz ardı etmek için, ayırma ve soyutlama ilkesi arasındaki farkı düşünün. 
Ayrılma ilkesini benimseyen bazı yasal sistemler de soyutlama ilkesini benimser. (4) ve (6) Örneklerinin açıklanmasının anahtarı olan ayırma ilkesi, mülkiyet sahipliğindeki değişikliklerin farklı yasal işlem türlerinin tamamlanması gerektiğini bildiren ilkedir. Soyutlama ilkesi, diğer taraftan, ayrılma ilkesi ile ayrılan işlemlerin yasal sonuçlarının birbirinden bağımsız olarak gerçekleştiği ilkedir. Örneğin, bir soyutlama ilkesi, geçerli bir satış sözleşmesinin kanıtı yokluğunda mülkiyet devrinin hukuki uyuşmazlıklarının feshedilmemesini sağlar. Bir Mülkiyet devri, yasal zeminden yoksun olsa bile yürürlüğe girer, bu durumda yasal zorluğa karşı savunmasız kalır (örneğin, haksız bir zenginleştirme olarak) (Maurer, 2001; Beale et.al. 2002: 20-1, 29-31).

Zımni beyan ve birincil sonuç arasındaki ilişkiyi, zımni beyanın birincil sonuç kanıtında gerekli bir bileşen olduğu şeklinde yorumlamak, birazdan belirteceğimiz hataya düşmektir. Bu yanlış, bir özelliği, yalnızca yasal sistemlerde, bir ayırma ilkesi ile soyutlama ilkesi olmaksızın, kendisine beklenmedik bir şekilde bağlı olan iradenin zımni beyanına atfetmektir.

Zımni bir irade beyanı oluşturmak için, aşağıdaki nitelikteki bir yargılama gereklidir.

İlk olarak, bir eylem, beraberindeki koşulların ışığı altında, birincil yasal sonucunu tespit etmek için incelenir. İkinci olarak, irade beyanı yasal zemininde tanımlanır. Üçüncü olarak, eyleme eşlik eden tüm koşullar dikkate alınarak incelenir ve daha fazla beyan için gerekli olan iradenin psikolojik varlı̆̆ı ortaya çıkarılır. Savigny şöyle diyor: 'zımni bir deklarasyonun varsayımı her zaman, kendisine eşlik eden tüm koşullarla ilgili bireysel eylemin gerçek bir yargısına dayanır' (Savigny, 1841: 131).

Özellikle yanılgı ve itiraz, bu çıkarımı dışlar. (Savigny, 1841: 131). ${ }^{14}$ Bu nedenle, iradenin zımni beyanı, kendine özgü özelliklerini iki şarta borçludur: (i) söz konusu davalarda olduğu gibi, bir eylemin iki ayrı ama yakından ilişkili şekilde yasal öneme sahip olma ihtimali; ve (ii) zımni deklarasyonun yasal sonuçlarına maruz kalmak için gerçek bir niyetin kesin kanıtının varlığı. Savigny'nin irade beyanı görüşünü detaylandırdıktan ve belgelediği davalarla gösterilen kuramlaştırılmamış ilişkiyi ortaya çıkarmak için yorumun biraz ötesine geçtikten sonra, artık iradenin zımni deklarasyonunu tanımlamak mümkündür. İradenin zımni beyanı, kişinin yasal haklarını ve/veya görevlerini, meydan okumadan korunmaya yardımcı olan ayrı bir yasal sonuçla ortaya koyan bir eylemle değiştirme niyetinin bir işaretidir. Bu tanım, Roma medeni hukuk davalarından ilham alabilir, ancak Alman hukuku gibi bazı modern hukuk sistemlerinde ayrılık ilkesinin varlığı, modern özel hukukta vasiyetname beyannamesi uygulamasının sürekli uygulanmasını garanti eder.

\section{V. İrade Beyanlarının Diğer Sınıflamaları}

Zımni beyanların belirli özelliklerinin önemi vurgulanarak, açık ve zımni beyanları arasındaki farkın, diğer farklı sınıflandırmalar ile nasıl ilişkili olacağı göz 
önünde bulundurularak, diğerleri eklenmiş veya hariç tutulmuştur. Buradaki amaç, belirli ayrımların alternatif zımni rıza beyanlarında yaşadıkları çöküşten korumaktır. İlk olarak, iradenin açık ve zımni beyanları arasındaki ayrımı, 'resmi' ve 'gayrı resmi' beyanlar ile tanımlanamaz (Savigny, 1841: 130). Bildirimler, etkileri, yalnızca bu iradenin bir ifadesi olarak sayılacak olan, pozitif olarak belirlenmiş bir eylem tarzının izlenmesine tabi olduğunda resmidir. (Savigny, 1841: 130). Eğer birinin yasal haklarını ve/veya görevlerini, böyle bir niyetin sinyalinin nasıl verileceğine ilişkin (örneğin, uygun görevlilerden önce) yasal kurallara uymayan bir şekilde değiştirme niyetini işaret etmesi gerekiyorsa, amaçlanan yasal sonuçlar doğmaz.

Bu durumda, irade resmi beyanları, formu 'vekili serbest bırakmayı amaçlayan' 'bilgi' beyanlarına aykırıdır (Savigny, 1841: 130). Şimdi, resmi bir vasiyetname beyanı yapmak kendi kendini yenilgiye uğratmak olur. Bunu yapmak için, milletvekillerinin hâlihazırda yasal bir görünüme sahip olan bir eylemin performansını tanımlamaları gerekir. Bu durumda, resmi bir prosedürün çeşitli avantajları - katılımcılara, maruz kaldıkları hukuki sonuçlara özel bir fikir vermeleri için sunduğu teşvik; beyanın yapılıp yapılmadığının belirlenmesinde anlaşmazlık olması durumunda nispi kolaylığı sağlar. Bu eylemi gerçekleştirmek için yeterli bir neden olmakla beraber bir kişi sadece performansından başka bir irade beyanı içerdiği sonucuna varamayacaktı. Tüm zımni beyannameler gayrı resmidir, ancak bu durum onları zımni yapan şey değildir. İkincisi, açı/ net ayrımcılığın, 'iradenin dış sonuçlardan çıkarımlı mı yoksa çıkarımsız mı olabileceği' üzerinde durup durmadığı 'kesin değildir.' (Savigny, 1841: 131).

İsteğe bağlı zımni beyannamelerin tespiti için çıkarımlarda bulunulmalı, ancak beyannameler söz konusu olduğunda bunlar hariç tutulmamalıdır. Açık bir beyanda, eğer işaret belirsiz veya karışık ise çıkarımlar dâhil olmak üzere yorumlama gerekebilir. Ancak bununla birlikte, daha ince bir ayrım yapilabilir. Çıkarım yalnızca, tek bir beyanın kesin şartlarını açıklığa kavuşturmak için açık beyanlar durumunda, bir eylemin ikinci bir yasal anlamı olup olmadığını belirlemek için yapılan zımni beyanlar durumunda gerekir. Açı ve zımni beyanlarda çıkarsama işlevindeki bu fark, her tür bildirimin tanımlanma şeklinden kaynaklanmaktadır. Savigny'nin beyanı böylece Hobbes'un aklını karıştıran şeyi ayırır.

Üçüncüsü, iradenin açık ve zımni beyanları her iki türden de 'gerçek' bir beyanı ve 'ibareyi istediklerimizin mevcut bir gerçek olduğunu açığa vuracağımız' beyanlardır (Savigny, 1841: 133). Gerçek beyanlarla birlikte, kurgusal beyannamelerin tersine gerekli niyetin psikolojik bir olgu olduğunu kanıtladığı ve pozitif bir hukuk kuralının vasiyetname beyannamesinin gücüne atfedildiği bir gerçektir. Kurgu, yanlış olduğu bilinen bir varsayımdır ve yasal bir kurgu, yasal 
etkisi olan ve yanlış olduğu bilinen bir varsayımdır. Bu durumda, yanlış olduğu bilinen varsayım, 'isteğin bir gerçek olduğu iddiasıdır'.

İradenin varlığı kanıtlanmış olarak alınır, böylece bir irade beyanı yapmanın yasal sonuçları ortaya çıkar, ancak iradenin varlığının kanıtlanmadığı bilinir. Bir yargıç, bir bildirimin gerçekleştiğini kabul ettiğini belirten yasal bir kural uyarınca belirli bir tür davranış sergiler. Örneğin, bir hâkimin, davanın tam anlamıyla kanıtlanmadı ̆̆ını bilmesine rağmen, bir hediye kabul ettiği varsayılabilir. ${ }^{15} \mathrm{Bu}$ yüzden kurgular, açık veya zımni irade beyannamelerinde olduğu gibi, bir dava koşullarının gerçek irade endeksleri sağladığı tartışmasını gereksiz kılmaktadır. Kurgusal bir bildirimin geçerliliğinin temeli, iradenin psikolojik varlı̆̆ı değil, kurgusal varlığıdır.

Bir kurgunun farklı nedenlerle yanlış/sahte olduğu biliniyor olabilir. Bir tanesi bile 'gerçek bir iradenin bile mümkün olmadığı' durumlarda, karşı eylemde bulunabilmesidir (Savigny, 184 1: 133). Bu gibi durumlarda, iradenin varlığının ispatlanmadığı bilinir çünkü iradenin var olmadığı bilinmektedir, "örneğin, alıcının hediyeyi bilmediği tespit edilmesi gibi". Alternatif olarak, 'bir şekilde iradenin bir işareti olarak yorumlanabilecek tek bir hareket bile' isteminin lehine tam bir kanıt eksikliği olabilir (Savigny, 1841: 133). Üçüncüsü, 'varsayılmış veya varsayılan olarak nitelendirilebilecek olan bir iradenin genel olasıllı̆̆ üzerine kurulmuş olan davalar' (Savigny, 1841: 133), 'genel olasılık' kanıtı olarak yeterli olmadığından kurguya da dayanır. Hibe sahiplerinin elindeki işlerin ispatlanması gereken kararlar oldukları için genellikle, bir işte kurgu olabilecek şekilde teslim edilir. (Fuller, 1967: 43, 46).

Buna karşılık, 'iradenin zımni beyanı... Her zaman gerçek bir irade beyanıdır' (Savigny, 1841: 133). Kesin bir irade beyanı için, dava koşullarının kişinin haklarını ve/veya görevlerini değiştirmek için gerçek bir niyete dair kesin kanıt sağladığını iddia etmek gerekir. Şimdi yukarıda verilmiş olan taktik ilanın ilk tanımını değiştirmek mümkündür. Kesin bir vasiyetname beyanı, eşlik eden şartlar ışığında, güvence altına alınmasına yardımcı olduğu kesin bir yasal kanıtla, bir kanundan doğan yasal haklarını ve/veya görevlerini değiştirme yükümlülüğünün gayrı resmi bir işaretidir.

\section{Zımni Rıza Beyanı}

Şimdi, "zımni irade beyannamesi" olarak adlandırılan yasal terimin incelenmesiyle, en sonunda zımni rıza vermeden önce, zımni rızanın irade beyanından ne kadar farklı olduğu göz önünde bulundurulma zamanının gelmiş olduğunu gösterir. Zımni irade beyanı ve zımni rıza, öncekiler aracılığıyla sonuncuya yaklaşma hükmüyle yeterince yakın olmakla birlikte, üç farklılık da kayda değer özel bir nottur. ${ }^{16}$ 
İrade beyanları ve rıza beyanları arasındaki en belirgin fark, birincisinin bir tür "yasal gerçek", yani "yasal ilişkilerin başlangıcını veya sonunu getiren olaylar" olmasıdır (Savigny, 1841: 104).

Öte yandan, rıza beyanları tamamen ahlaki olabilir. Boş zaman aktiviteleri için ücretsiz asansör temin etme sözü veren arkadaşlar, kendilerini yasal olarak bağlama niyetinde değillerdir sadece ahlaki olarak bağlama niyetindedirler. Burada, yine özel olarak yasal veya ahlaki bir gerekçe yoktur. Bazı tanıdıklar, karşlığında bir şeyler umduklarından vaatte bulunurlar.

İkincisi, bir irade beyanı gerçek veya kurgusal olabilirken, rızaya istekli olma ruhsatının psikolojik gerçeğinin kesin bir kanıtı bulunmalıdır. Bireylerin başkalarının özel izinleri için saygısız davranıp davranmadıklarını tespit etmenin alakasız olup olmadığına dair ahlaki bir teoriye izin vermek gerekmez. Koşulların böyle bir konuyla ilgisiz kalması durumunda, kişi onamdan (izin, rıza) bahsederek meseleleri süslememelidir.

Örneğin, kocalar eşlerine tecavüz etmekten suçlu bulunamazlarsa, bu eşlerin her zaman birbirleriyle cinsel ilişkiye rıza gösterdiğinin kanıtı değildir. ${ }^{17}$ Rıza, irade beyanının aksine, her zaman gerçek ve asla kurgusal değildir. Üçüncüsü, gerçek bir irade beyanı, bir kişinin yasal haklarını değiştirme niyetinde olduğu sürece, yasal görevlerini değiştirmesini gerektirmez.

Örneğin, birinin yasal görevlerini değiştirme niyeti gerektirmeyen bir tür gerçek irade beyanı, bir kişinin otobüse gazete bırakması gibi mülkiyet hakkından vazgeçme niyetini işaret eden bir inkâr etme eylemidir. Aksine, bir onay beyanı her zaman bir yükümlülüğün üstlendiğine işaret eder. ${ }^{18}$ Eğer geçerliyse, her zaman belirli bir kişiye başka bir korelasyon hakkı verir. Bu hesaba göre, rıza ahlaki ve/veya yasal bir yükümlülük üstlenme niyetinin bir işaretidir. Açıkça yapılan rıza beyanı, beraberinde getirdiği koşulların ışığında, gelişmesine yardımcı olduğu çok açık bir hukuki veya ahlaki ifadeyle, bir eylemden çıkarılan bir yükümlülüğü yerine getirme niyetinin gayrı resmi bir işaretidir.

Şu andan itibaren, bu zımni rıza kavramına yapılan atıflar, 'zımni rıza beyanı' terimi kullanılarak, diğer zımni rıza kavramlarından ayrılacaktır.

\section{Neden Zımni Rıza Beyanı?}

Rızanın açıkça beyan edilmesi, niyetin koşulunu yerine getirerek, genel rıza anlayışımızın tutarlılığını korur. Bir yükümlülük üstlenmek gerçek bir niyeti içerir ve gerektirdiği çıkarım ise, protesto da dâhil olmak üzere, beraberindeki tüm koşulların dikkate alınmasına izin vermelidir. Yasanın sonuç olarak ortaya çıkmasının karşılığı, kesin bir rıza beyanının verildiği sonucunu gerektirmez. Rıza beyanı, kasıtlılık koşulunu yerine getirdiği için, kasıtlılık şartının, rızanın onayının önemsiz olmayan kullanımını engellemediğini göstermektedir. 
Bütün rızanın kasıtlı olduğunu ve önemsiz olmayan bir zımni rıza kavramını onayladığını söylemek mümkündür. Ek olarak, rızanın açıklanma beyanının entelektüel olarak diğer rızanın kabul edilme anlayışlarından üstün olduğunu iddia ediyorum. Bu iddiayı desteklemek için, zımni rızanın önemsiz rakip beyanları tartışılmalı ve istekli bulunmalıdır.

Burada, zımni rıza temelli siyasi yükümlülük hesabının savunulmasında öne çıkan iki zımni rıza kavramını inceliyorum: Murphy'nin Hobisi, çıkarım gerektiren işaretlerle rıza olarak zımni rızayı ve Simmons'ın geleneksel rıza hükmünü açıklar. Burada ileri sürülen her iki hesaba itiraz, her iki yazar da rızanın kasıtlı olduğunu kabul etmesine rağmen, zımni rıza beyanlarının aslında bu şartı yerine getirmediği yönündedir.

Genel rıza niyetlerini kabul ettikleri ile bu kritere uymayan başarısız özel davranış biçimleri arasında bir arabuluculuk vardır.

Her şeyden önce, zımni rızayı anlama önerisine çıarım gerektiren işaretlerle rıza gösterir. Murphy'nin Hobbes'ı yorumlaması: "Sözleşmenin belirtilerini açıça ifade etmek, acentenin iradesini açıkça ifade edenlere aittir; zımni sözleşme işaretleri, aracının gerçekleştirme isteğine sahip olmamızın gerekçesini vermemizi gerektiren asıl şeydir. (Murphy, 1994: 85) Diyelim ki, II. Bölümde ortaya çıkan bir kargaşanın 1şı̆̆ında, Murphy'nin, 'gerçeğe sebep olma çabalarının' özellikle tek bir işleme ait bir eylemin anlamını ortaya koymaya yönelik olduğu açıklığına cevap vereceğini varsayalım.

Böyle bir açıklama yapıldığında, Murphy'nin, savunulabilir bir zımni rıza beyanını yeniden inşa etmeyi istiyorsa, 'gerçekleştirme isteğinin' kesin bir kanıtı oluşturmak için yeterli bir çıkarım ilkesini belirtmesi gerekmektedir (Murphy, 1994: 73). Murphy'nin önerdiği ilke "anlaşılabilirlik ilkesi” dediği şeydir. "Anlaşılabilirlik ilkesi”, "eylemlerin sadece vekil için bir miktar teminat sağlamayı amaçladığı ölçüde anlaşılır" olduğu anlamına gelir (Murphy, 1994: 86), burada "iyi" olan "kişinin kendi kendini koruması" dır. (Murphy, 1994: 84) Daha sonra şunu sorar:

Yüklenicinin, gerçekleştireceği iradesinin açık bir belirtisi bulunmadığı teklif edilen bir sözleşmeyi düşünün. Ayrıca, böyle bir sözleşmeye girmemenizin, kendisi (kız ya da erkek) için bir fayda sağlayacak şekilde görülemediğini varsayalım. Böyle bir durumda, en uygun yorumlama, anlaşmalı tarafın yapacağı belirtilerini gerçekleştirmeye istekli olduğunun işaretleri olduğu anlamına gelmez mi? Bu yorumlayıcı ilke, Hobbes'in sözleşmelerdeki hesaplarından destek almış gibi görünüyor. Belli bir performans istemediğinizi ve bunun sizde bir felakete neden olacağını bilirsem ve bunun da doğru olduğunu bildiğinizi düşünmek için iyi bir nedenim varsa, yaptığınız işaretlerin neredeyse tümünü isteksiz olduğunuza bir işaret olarak 
yorumlamak için bir gerekçem var. Eylemlerinizi bu şekilde yorumlamazsam, davranışınızın tamamen anlaşılmaz olması muhtemeldir (Murphy, 1994: 86).

Şimdi, eğer "anlaşılabilirlik ilkesi", Murphy'nin önerdiği gibi, bireylerin onayladığı şeyleri ortaya koymaksa, yalnızca onay vermenin amacının her zaman bir kişi için "fayda" elde etmesi olduğu durum bu olmamalıdır. Bireyler böyle bir avantaj elde edebilecekleri zaman gerçekten onay vermelidirler. ${ }^{19}$

Yine de, Hobbes'un yorumlaması adına, bireylerin yalnızca kendi kendilerini korumayı amaçladıklarını ve yanlış anlaşılmaların veya eşitliklerin, anlaşılabilirlik ilkesini uygulayanlar için bir sorun teşkil etmediği varsayılsa bile, bu varsayım problemlidir. Bu sorunun nedeni, anlaşılabilirlik ilkesinin bir müvekkilin işaretleri üzerinde baskılanmasının nedeni, ölüm de dâhil olmak üzere potansiyel olarak dezavantajlı bir sonucun farkında olmanın ve bunu önlemek için gerekli düzenlemelere yönelik sinyal anlaşmasının durdurulmasının mümkün olmasıdır.

Belli bir dezavantajdan kaçınmak için belirli bir sözleşmenin gerekli olduğu düşünüldüğü halde, daha faydalı bir teklif beklentisiyle, bir dezavantajın birinin isteğini, o zaman ve oradaki düzenlemeye ve bunun yerine beklemesine işaret etmeyi gerekli kılacak kadar yakın olmadığına inanılabilir.

Bu gibi durumlarda anlaşılabilirlik ilkesi kullanılmışsa, 'düşüneceğim' veya 'yeterince teklif etmiyorsunuz' gibi ifadeler iradenin belirtileri olarak yorumlanmalıdır. Bunu yapmak bir kurguya dayanmak olacaktır, bu da karşılıklı yarar sağlayan bir teklifin masaya konması üzerine pazarlık olasılığını önleyen bir kurgudur.

Öyleyse, böyle bir anlaşılabilirlik ilkesinin temel sorunu,- bir zamanlar büyütülen Hobbes dili varsayımları gevşetilince, rızanın potansiyel bir 'faydadan' çıkarılamamasıdır. Kabul edilirse, anlaşılabilirlik ilkesi, bir yargıcın bir kurguyu kullanırken dikkat etmesi gereken kötü bir ilke olamaz. Ancak, rızanın gerektirdiği iradenin psikolojik varlığını tanımlamaması, onaydan anlam çıkarmaya çalışması onu tamamen geçersiz kılar.

Murphy'nin zımni rıza ifadesi, sözleşmelerin potansiyel olarak kurgusal niteliğini rızaya istemeden aktarır. Son olarak, A. J. Simmons tarafından savunulan alışılmış taciz onay iznini dikkate alın. Bu son beyanda Simmons şöyle diyor:

Smith'in rızası, Smith'in kasıtlı ve uygun bir şekilde başka bir Smith'in niyetini, dolayısıyla yeni haklara karşı ve/veya diğerlerine yeni haklar devretme niyetiyle iletişim kurmasıdır. Yani, düşündüğüm şey Locke'un rıza anlayışının kendi başına oldukça makul bir anlayış olduğudur.

Locke'un beyanında açık rıza, (bir sinyal veya dalga gibi) sözlü veya yazılı bir söz veya yemin ya da kabul görmeyi açıkça belirten olumlu 
ancak sözsüz bir davranış gibi, doğrudan ve açıkça geleneksel olanın rıza vermesi gereken bazı doğrudan ve açık türlerin olumlu eylemleriyle verilir. Aksine, zımni rıza, Locke'un söylediği gibi "açı" olmadan verilen rızadır - yani, sözlü veya başka türlü doğrudan ve açıkça olumlu davranışlar olmadan olan rıza. Zımni rıza, amacı sadece rıza göstermeyen eylem türleridir - yine de, yükümlülükleri yerine getirme ve/veya hakların yerine getirilmesi için bir seçim yapma şartı olarak sayılan başka türlü eylemler tarafından kabul edilen bir şeydir. Zımni rıza davranışı, açık, serbest seçim durumlarına belirleyici tepkiler vermesi nedeniyle, ahlaki açıdan önemli bir kararın geleneksel olarak beklendiği veya uygun olduğu bir durumdur (Simmons, 2001: 166).

Zımni rıza tanımının bu olup olmadığına dair ilk şüphe, Simmons'ın rızanın kasıtlı olarak onaylanması ile tutarlı kaldığına dair bir şüphe, "seçim yapma olarak sayılan şartlar", "seçim olarak sayma" ve 'seçim belirten tepkileridir.

Yasal ve/veya ahlaki sonuçların kasıtlı olarak 'yeni yükümlülükler üstlenme ve/veya yeni haklar devretme niyeti' olmasa bile davranışlarda bulunmalarına neden olduğu durumları tanımlamak için kullanılabildiğinden bu ifadeler belirsizdir. Örneğin, Gordon Brown altındaki İngiliz hükümetinin bir kimlik kartının çıkarılmasını pasaport başvurusu yapmayı şart koşmasının bir nedeni, vatandaşın kimliğinin çıkarılması için onay vermesi gereken bir senaryodan kaçınmaktı. Simmons'ın zımni rıza tanımının, hâlihazırda iyi bir şekilde kamuya açılandığı sürece, bu tür önlemleri hariç tutacağı çok açık değildir.

Simmons'ın zımni rızası varsa ve rıza niyetinin şu anki karakteristiğini yerine getirme şansına sahipse, III-VI. Bölümlerde geliştirilenlere yaklaşan bu ifadelerin sırasıyla "niyet işareti", "rıza sinyali" ve "beyan sinyali" ile değiştirilmesi mümkün olmalıdır. Simmons'ın tanımının böyle bir revizyona izin verdiğini varsayarsak, zımni onay veren bir eylemin bir onay belirtisi olarak hizmet etmekten başka bir 'noktası' olduğunu varsayın.

Bundan sonra, bir bireyin rızayı işaret etmek yerine başka bir işlemi yapmak için bir nedeni olabileceği varsayılır. Bu nedenle, sadece bu sebeple gerçekleştirildiyse, müvekkil rıza gösterme niyetini işaret etmeyeceğinden rıza göstermez. Bazı gerçekler, kanunun gerçek dayanağına ek olarak, aynı zamanda bir rıza kanunu olduğu iddiasını haklı çıkarmak için de gereklidir.

Simmons, 'açık, özgür seçim durumu' gerçeğinin yeterli olduğunu düşünüyor ve kesinlikle bu durumun açık olması gerektiğini düşünüyor. Kişi neyi onayladığının ve nasıl yapılacağının farkında olmadığı sürece kimseye rıza veremez. Ancak 'açık, özgür seçim durumu' yeterli değildir. Herhangi bir rıza gösterme niyetinden bağımsız olarak bir tür eylem gerçekleştirme nedeni varsa, hiçbir genel 
kriter rıza gösterme niyetinin böyle bir eylemin her belirtecine eşlik ettiği iddiasını ortaya atamaz.

Böyle bir genel kriter olarak 'açı, özgür seçim durumunun' inşası yeterli olamaz. Simmons, "açık, serbest seçim durumu" nun "geleneksel olarak beklenen veya uygun olan" kriterleriyle birleştiğinde onay verilmesini sağlayabileceğini öne sürerek bu itiraza yanıt verebilir. Bu argüman çizgisinde, belirli seçimlerin nasıl rıza izniyle gösterileceğine dair mevcut prosedürlere uygun hareketlerde bulunmak doğrudur.

Bununla birlikte, buradaki belirleyici cevap, x'in bağımsız bir amacı v olsa da, x'in bağımsız bir v'ye sahip olmasına rağmen, z'nin gerçekleştirilmesi için herhangi bir rıza gerekmediğine dair ahlaki ya da yasal bir sonucun olmadığı kanaatidir. 'Serbest hareket' (Savigny'nin terimini kullanmak için) yeterlidir. Bu cevabın azalması durumunda, eylemler veya eylemsizlik kasıtlı olarak kullanıldığında bağlayıcı rıza gösterilebileceği konusunda ısrar eder. Bir eylemin "net, özgür seçim durumunda" olduğu gibi z sonucuna sahip olduğunu bilmek, onu amaçlayanı söylemek değildir. Özgür bir eylemi bir rıza eyleminden ayıran boşluk, herhangi bir farkındalıkla ihlal edilemez.

Sadece birinin yükümlülüklerini değiştirme niyeti ile ihlal edilebilir. Böyle niyetin yokluğunda, bir kurgunun çağrılması gerekecektir, bu sayede bir eylemin sonucunun 'farkındalığı' sanki onu yapmak olduğu niyeti ortaya çıkacaktır. Bir kişi bu tür bir kurgunun kullanımı için yasal düzenleme kursa da, tanıtımı için bize rıza göstermeye daha fazla yaklaştırmayacaktı. Kurgusal rıza bir çelişkidir. Simmons'ın zımni rıza gösterme ifadesi, Murphy'nin yaptığı gibi, haklı olarak ısrar ettiği rızanın niyetini koruyamamaktadır.

Murphy ve Simmons'ın zımni rıza tanımlama girişimleri “özgür seçim durumu", yalnızca genel prensipler veya genel çevre tutumlarıyla rıza göstermeye çalıştıkları anda, niyetin koşulunu kirletme yükümlülüğe sahiptirler. Bu, gerçek bir iradenin psikolojik varlığını tespit etmek amacıyla bireysel bir durumun koşullarının gerekli incelemesini engeller. Genel rıza niyetine olan bağll1ıklarını iyi yapmak için hem Murphy hem de Simmons alternatif bir zımni rıza beyanına ihtiyaç duyar. Niyetliliğin koşulunu karşılayan başka herhangi bir zımni rıza beyanının olmaması durumunda, burada önerilen zımni rıza kavramını benimsemeleri gerekir.

\section{Zımni Rıza Ve Siyasi Yükümlülük Beyanı}

Zımni rızanın karmaşıklığı ve kasıtlılığını geri kazanmak, siyasi yükümlülüğün açık rızasıyla ilgili iki tür iç görü sağlar. İlk olarak, zımni rıza beyanı, siyasi yükümlülük beyanına dayanan bir zımni onay istemcisinin, zımni onay üzerine siyasi yükümlülüğü temellendirmek için yapmış olduğu ve yapması gereken iddiaların niteliğinin altında olduğumuzu açıklar. İkincisi, bununla birlikte, zımni 
onay beyannamesi, zımni onay temelli siyasi yükümlülük teorisinin bütününün savunuculuğunu sorgulamaktadır. 'Zımni rıza temelli siyasi yükümlülük teorisi' ile belirli bir devletin sınırları içindeki kişilerin, zımni bir rızayla, daha önce hükümet tarafından ilan edilen kurallara uymak için ahlaki bir yükümlülük kabul ettikleri fikrine katılıyorum. ${ }^{20}$ Genel olarak tanımlanmış belirli davranış türlerini rapor edin veya yazınız.

İlk noktayı incelemek için, siyasi yükümlülük esaslı açık bir mutabakata dayalı iddialara ait niteliği, Locke'un Hükümet Üzerine İkinci İncelemesinde zımni rıza için yapılan temyiz başvurusunu göz önünde bulundurun:

Herhangi bir hükümetin kanunlarına tabi kılmak için bir erkeğin rızasının yeterli bir beyanı olduğu anlaşılmalıdır. Mevcut durumu ilgilendiren açık ve zımni bir rızanın ortak bir ayrımı vardır. Hiç kimsenin şüphesi olmamakla beraber, herhangi bir topluma giren bir erkeğin açık rızası, onu o hükümetin konusu olan toplumun mükemmel bir üyesi yapar. Zorluk, zımni bir rıza olarak görülmesi gereken şey ve ne kadar bağlandığıyla, yani, herhangi bir kimsenin rıza göstermesi için ne kadar bakılması gerektiği ve bu nedenle hiçbir ifade vermemiş olduğu herhangi bir hükümete sunulmasıdır. Buna diyorum ki, herhangi bir hükümetin egemenliğinin herhangi bir kısmına sahip olan bir mülkiyete veya eğlenceye sahip olan her insan, bu nedenle zımni rıza göstermez ve bu hükümetin yasalarına itaat etmek zorunda kalır. Bu zevk sırasında, altındaki herhangi biri; $\mathrm{Bu}$ mülkün mülkiyeti toprak, kendisine ve mirasçlarına sonsuza dek mi, yoksa sadece bir haftalığına mı kalacak; veya karayolunda zorlukla seyahat edip etmediği; ve aslında, o hükümetin sınırları içerisinde herhangi birinin varlığına kadar uzanır (Locke, 2003: 119).

Öncelikle, yukarıda sayılan sahte rıza izninin hiçbirinin bu sahte rıza itirazına dair tatmin edici bir iç görü sağlamadığına dikkat edin. Burada Locke'un zımni rıza olarak ve hala sessiz kalmanın rızası olarak kabul ettiği önerisi bariz olmayan bir başlangıçtır. Locke'un örnekleri asıl şartı yerine getirmiyor (otoyolda özgürce seyahat ediyor). Dahası, örnek olarak listelediği tüm eylemlerin sözsüz olarak yapılabileceği doğru olsa da, bu gözlem Locke'un haklı olduğu yerde bazı zorluklar ortaya koymaktadır.

Bunu yapmak için, zımni bir rızanın verildiği eylemler sınıfının en genel tanımını, yani bir hükümetin topraklarında herhangi birinin varlığına kadar ulaşan eylemleri ele almak gerekir. Bu son söz, onayın, kelimelere dökülür dökülmez zımni olmaktan vazgeçtiği anlamına gelmez ve Murphy'nin, zımni onayının çıkarılan işaretin "ikamet" veya "kamu malları" kullanımını içermesi gerektiği iddiasını geçersiz kılar. (Murphy, 2006: 97-101).

Kuşkusuz bu söz, kendi başına, Hobbes'in zımni rızanın çıkarım gerektiren işaretler tarafından onaylandığı yönündeki önerisini dışlamaz. Ancak gördüğümüz 
gibi, bu öneri, Locke'un gerektirdiği çıkarımın kendine özgü işlevi hakkında yeterince şey söylemez.

Son olarak, Simmons 'zımni rızanın' sadece rıza göstermeyen eylem türleri 'tarafından rıza gösterdiğini de düşünerek, davranış sınıfı kucaklayan bir kişi Locke'un böyle bir seçimi hesaba katabilecek bir yorum arayışında metni araştırdığında kesinleşir.

Kısa bir süre sonra, Locke 'herhangi bir hükümete ait topraklara girmeyen ve statüsünde olmayan herkese bağlı yerel bir koruma ve saygı' anlamına geldiğini söyler. (Locke, 2003: 122). ${ }^{21}$ Bu yorum, Locke'un, bir devletin sınırları içerisinde bu sınır içerisinde kalmasını önerme sebebinin, öncelikle bu davranışların özel olarak ahlaki bir noktaya sahip olduğunu öne sürdüğünü söylemektedir.

Bu da Devletten "korunmanın "haklı" olmasını sağlarlar. ${ }^{22}$ Yorum, ikinci olarak, yasaya uymak için eşzamanlı olarak yapılan onay bildiriminin bir hükümetin bu sayede korunma hakkını göz ardı etmesini yanlış olduğunu öne sürüyor. Bu düşünce, yalnızca "savaş" ilanında protesto uygulayanların, korunma hakkının güvence altına alınmaması gereken bir protesto eylemi yapanlar olduğunu ifade eder. Locke'un, zımni rızanın ilanını çağırdığını düşünmesi, bu iki düşünceyi kaydetmenin tek yoludur.

Metinsel yorumlamanın ötesine geçerek, onay izninin açık beyanının, ilerlemenin herhangi bir asıl rızasını içeren bir siyasi yükümlülük teorisi savunucusu olduğunu kabul ettiği iddiasını göz önünde bulundurun. Birincisi, bir devletin sınırları içindeki insanlar tarafından gerçekleştirilen bir sınıf davranışı ve yalnızca bu davranışların hükümete karşı belirli bir ahlaki davranış olduğu fikrini savunmaları gerekir.

İkincisi, bir kişinin yasaya uyma izninin bir hükümetin bunu ihlal etmesini engellediğini iddia etmesi gerekir. Üçüncüsü, bu ahlaki ifadeye sahip olmasının yanı sıra, onları oluşturan kişi sayısı, yukarıda belirtilen eylemler sınıfının, aynı zamanda genel olarak ya da bunları uygulayan herkes tarafından ya da önemli bir sayıda yasaya uyması için zımni bir onay verilmiş olduğu bir davranış sınıfı olduğunu iddia etmek zorundadirlar.

Siyasi yükümlülük yaklaşımı, ilk iki tür iddiayı ilerletmeye çalışırsa, yalnızca siyasi yükümlülüğe yönelik zımni bir onay temelli yaklaşım olarak nitelendirilir. Siyasi yükümlülüğe yönelik zımni bir rıza temelli yaklaşım, bütün bir kişi sınıfı veya bir kısmı önemli ölçüde, yalnızca mevcut veya akla gelebilecek bir toplumda, üçüncü iddianın doğru olduğu, yani yasaya uyma izninin genel olarak bu şekilde zımni ilan edildiği durumlarda, siyasi yükümlülük teorisi unvanın hak eder. $\mathrm{Bu}$ dağılım göz önüne alındığında, bu iddiaları ilerletmek için hangi sınıfların seçileceği açıktır. 
Teorinin amacı, hükümete karşı yasaya uyma iznini işaret eden zımni bir rıza gösterme eylemini tespit etmektir. Bu nedenle, herhangi bir savunmanın, yasalara uyma izniyle güvence altına alınan ahlaki açıdan bir eylemler sınıfı seçerek başlaması gerekecektir. Bu özel ihtiyaç, adayların alanını önemli ölçüde daraltmaktadır.

Birincisi, asıl sonucu ahlaki bir görev varsayımı olan hareket sınıflarını dışlar. Bu tür davranış sınıfları uygun değildir, çünkü sonuçlarının bir görevi yerine getirme taahhüdünü güvence altına almaları için bireylerin taktik olarak onay vermeleri için çok az motivasyona sahip olacaktır.

İkincisi, asıl ahlaki değeri vatandaşlık hakkının kazanılması olan hareket sınıflarını içermez. Siyasi hakların elde edildiği bir hareket sınıfı seçmek uygun değildir, çünkü yasaya uyma izninin bu hakların güvence altına alınmaması gerektiğini; yasalara uymayı kabul eden turistlerin oy kullanma haklarının olmaması gerektiğini savunur. Bu, sadece bir seçenek, yani kişilerin, bir toplumun korunma hakkını, yani siyasal toplum içinde, diğerlerinin yaralanmasına ve teşebbüslerine karşı, 'yaşam, özgürlük ve mülk alma hakkı' kazanma eylemi seçilmesini sağlar. Burada, hükümetin yanlış yaptığı ve yasaya uymaya razı olan bir kişi tarafından tutulan bir koruma hakkını ihlal ettiği için yanlış bir iddia yapılabilir.

İlginç bir şekilde, bu sonuç alışılmış uygulamalara aykırıdır; bu nedenle zımni rıza analizi eksikliğinin, yasaya uyma riza göstermeye uygun olabilecek hareket türleri için öfkeli bir arayışa eşlik ettiği görülmektedir. Zımni rıza teorik olarak anlaşıldığı zaman, önemsiz ortak akla dayalı terimler yerine zımni rıza beyanı olarak sadece bir aday vardır.

Bununla birlikte, bu iddiaları ve gerekli başlangıç noktalarını belirlemek, kesin bir rıza temelli siyasi yükümlülük teorisinin başarılı olabileceğini kabul etmek değildir. Öncelikle, bu teorinin zımni onayını tutan en belirgin iki versiyonunu ele alın, genellikle, Locke ve Simmons'ın versiyonları verilir. Locke'un "yerel korumanın" tadını çıkarma eylemini değerlendirmenin anahtarı, yasalara uymak için kesin bir onay vermesidir. Zımni rıza, o hükümetin toprakları içinde herhangi birinin varlığına kadar uzanır '

Locke'un ifadesinin genelliği, bir bildirimin gerçekleştiğini varsaydığı şartı altında bir davranış türü ortaya konduğunda, gönderilen kararın sağlandığ varsayımını ortaya koymaktadır. Belirli bir vakanın koşullarının incelenmesi önemsizdir.

Aksine herhangi bir kanıtın sergilenmesi (savaş ilanının yanı sıra) yasaktır. Ancak bu, niyetin koşullarını ihlal eden bir kurguya dayanmaktadır. İkincisi, Simmons'ın niçin zımni rızanın "geniş çapta uygulanabilir olmasa bile, siyasi yükümlülük teorisi" olarak savunulabilir bir rol oynamasına neden olduğu üzerine Hume'n sonrası argümanı ele alalım (Simmons, 2005: 341). 
Hume'ten bu yana, zımni rıza temelli siyasal yükümlülük teorisi karşıtları, eleştiriler ileri sürdü; örneğin, itaatin uyguladıkları şeylerle ilgili olarak, potansiyel rızaların açıkça seçildiğine dair açık bir inanç eksikliği gibi muafiyet ilanında zorluklar ve maliyetler ve dış koşulların belli başlı konuları üzerinde durdu. (Hume, 1875: 451).

Siyasi yükümlülüğün temelini atmada zımni rıza kullanımına yönelik bu itirazlar, sadece Simmons'ın "açık, özgür seçim durumu" olarak adlandırdığı şeyin, zımni rıza olarak belirli eylem türlerini saymak için gerekli arka plan olarak henüz mevcut olmadığını reddetmektedir. Simmons'a, koşulların hem 'açık' hem de 'özgür' bir durum yaratacak şekilde uygun şekilde değiştirilebilmesi durumunda, bu eylemlerin yasalara uymak için zımni bir rıza olarak sayılacağına cevap vermeleri için yetki verilir.

Simmons'ın, yukarıda belirtilen iki türün iddialarıyla açık, özgür seçim durumu 'fikrini desteklediğini, böylece görüşünün siyasi yükümlülüklere yönelik zımni bir rızaya dayalı bir yaklaşım olarak sayılabileceğini, yani, insanların karşı karşıya geldiğini' varsayalım. Hükümetin ihlali durumunda hareket etse bile, rızası olmayanların hiçbir sıkıntı çekmemesine rağmen, belirli bir devletin sınırları içerisinde kalan açık ve özgür seçim, bu şekilde bir koruma hakkı elde etmelidir. Locke aleyhindeki eleştiriler hala geçerli olurdu. Simmons, bütün bir aktör sınıfının, yasaya uyma izninin bir hükmü ile sınırlandırıldığının temel tezini iyi yapmak için yeterince genel olan bir rıza belirleme kriterini benimsemesi gerektiğinden, bir kurgu uygulamaya koyma niyetinin ihlal edilmesine mecbur bırakılmıştır.

Noktayı göstermek için: barış̧̧ıl eylemler, bireyler itaatin bir seçimin sonucu olduğu inancına sahip olsalar bile ve girişleri olmayan, yasal formdan bağımsız olarak, daha ileri bir seçime sahip bir toplum olsalar bile, tam anlamıla rıza göstermezlerdi. Kısıtlanmış ve yerlileri olmayan, kendilerini yok etmeleri için bütün bir maddi teşvikler paketi ve sosyal ve psikolojik destek sistemleri sunmuştur. Meseleleri değiştiren eski ülke, topraklarında açık ve barışçıl olarak varlığını 'rıza' olarak kabul eden bir yasa çıardı. Kanıt, yasaya uyma yükümlülüğünü yerine getirmek için gerçek bir niyetten yoksundur.

Son olarak, zımni rızaya dayalı siyasi yükümlülük teorisinin daha az kapsamlı bir versiyonunu düşünün. Bu versiyonda, üçüncü iddia, hükümet bölgelerinde kalarak ahlaki bir korunma hakkı üstlenen kişilerin önemli bir kısmının bu şekilde yasalara uymalarına izin vermesidir. Fakat teorinin bu versiyonu bile çözülemez bir zorlukla karşı karşıyadır. Bunu rahatlatmak için, yasal bir bağlamdan alınmış daha önceki açıklamalı rıza beyanı örneklerini düşünün. Bu örneklerde, birincil yasal vekiller kendi irade beyanlarının sonuçlarıdır. Gerekçeli olarak kesin bir onay beyanına gerekçelendirilmesinin sebep olduğu eylem ve buna eşlik eden eylemler, 
aracının bir tür yasal işlem yapma, örneğin yasal bir devir işlemini tamamlayan bir irade beyanı gibi bir niyetini zaten içermektedir.

Zımni rızaya itiraz eden siyasi temyiz aynı eylemden başlayamaz. Belirli bir devletin sınırları içerisinde kalma sürecinde korunma hakkının varsayılması, serbest bir hareketten daha fazlası değildir.

Hükümetle ilgili olarak, öncelikle serbest bir eylem olan ve esasen ahlaki bir niyetten yoksun olan bir eylemden gönderilen gizli bir beyanname çıarımı yapmak gerekir. Bu çekingenlik, henüz kurguya uygun olmayan bir çare istemeyecekse, mutsuz bir sonuçla birleşir. Zımni rıza temelli yaklaşımın savunucularını yalnızca siyasi bir yükümlülük teorisi olmadan değil, aynı zamanda hükümetin çok sayıda olmayan bir kişiyi koruma hakkına aykırı davranması durumunda rıza gösteren kişilerin yanlış yapmayacağını kabul etmek zorunda bırakıyor.

\section{Sonuç}

Bu yazının ilk amacı, daha entelektüel bir şekilde ikna edici bir zımni onay iznini sağlamaktı. Bu görevi, tam bir rıza beyanı kavramı oluşturarak sürdürdüm. Açıkça yapılan rıza beyanı, eşlik eden çevre davranışları ışığında, karara varmasına yardımcı olan belirgin bir hukuki veya ahlaki ifadeyle, bir eylemden çıkarılan bir yükümlülüğü yerine getirme niyetinin gayrı resmi bir işaretidir. Bu zımni rıza kavramı, zımni rızanın ortak akla dayanan görüşlerinin önemsizliğinden muaftır ve zımni rızanın önemsiz olmayan rivayeti anlayışlarına göre üç avantajı vardır. Öncelikle ve en önemlisi, onay izninin açıklanması, rızanın rakip tasavvurlarını savunanların genel bir özelliği olarak kabul ettiği, ancak zımni rızanın onayına saygisızlıkta bulunma koşulunu yerine getirir. Pratik olarak, izin belgesinin açılanması, örneğin bir ayrılık ilkesini benimseyen özel hukuk sistemlerinde, yasada bir dereceye kadar destek içerir. Teorik olarak, zımni bir rıza temelli siyasi yükümlülük teorisinin savunucularının yapmış olduğu ve yapması gereken iddiaların niteliğini aydınlatır. İkinci bir ilgili amaç ise zımni rıza temelli siyasi yükümlülük teorisinin yenilmezliğini göstermektir. Bu teoriye karşı yapılan geleneksel itirazlar, yalnızca uygulanabilirliğini sınırlayan dışsal hususları gündeme getirmektedir. Avukatlarının, yaygın olarak uygulanabilir olmasa bile, prensipte savunulabilir olduğuna yanıt vermesine izin verir. Bu cevabın gerekçesi şimdi kaldırılmıştır. Locke ve Simmons benzeri teorinin geniş versiyonları, bir kurgunun istihdamına yol açan yükümlü bir riza oluşturmak için genel kriterler kabul etmeye mecburdur ve kurgusal rıza, saçmalıkların niyetini ihlal ettiği için saçmadır. Bu tür beyanlar sadece teşhisi gerektirir. Savigny'nin Sistemini araştırmakla izin verilen teşhis, istemeden beyan edilebilecek potansiyel olarak kurgusal bir karakter olan rızaya müsaade etmeden müracaat ettikleri veya başka rıza beyanları ile serbest hareketleri karıştırdıklarıdır. Yaklaşımın daha az kapsamlı versiyonları bile benzer bir çare bulmak için hiçbir teori sunmuyor. Sonuç olarak, zımni rıza beyanının 
onaylandığını doğrulamak mümkündür ve içgüdüseldir, ancak siyasi yükümlülüğg̈ zımni onay yoluyla açıklamak imkânsızdır. Zımni rıza temelli siyasi yükümlülük teorisinin eleştirmenlerinin artık tüm rivayet konuşmaları önemsiz olarak görülmemelidir. Adayları, kullanımlarını gözden geçirenler olmalıdırlar.

\section{Notlar}

Önerileri ve eleştirileri için Timo Juetten'e ve bazı anonim hakemlere teşekkür ediyorum.

1- Bu, zımni rızanın siyasi tartışmaları için 'olağan bağlam' tanımının ilk unsuru Knowles'ın pozisyonunu açılamaz. (Knowles, 2010: 106-107). Knowles, açık veya zımni olsun ya da olmasın, yasalara uyma yükümlülüğünü üstlenmek için yeterli ancak gerekli olmayan bir koşul olarak kabul eder. Rıza temelli siyasi yükümlülük hesaplarını yalnızca, bireylerin rıza göstermeleri durumunda (ve rıza göstermeyenlerin de böyle bir yükümlülüğü üstlenmediğini) yasalara uymak için ahlaki bir yükümlülük üstlendiklerini iddia ettiğini söyler (Knowles, 2010: 52). Bu nedenle anlaşılan, rıza bazlı beyanlar, bireylerin yasalara uymak için ahlaki yükümlülükleri olduğu gerekçesiyle diğer sayılarla birleştirilebilir. Ancak yazar, verilen bir yükümlülüğün kabulünde gönüllü ve istemsiz gerekçelere eşzamanlı olarak nasıl önem vermenin mümkün olduğunu açıklamamaktadır. Simmons'ın ifadelerinde, rıza teorisyeni kaçınılmaz yararlar veya çıkarların korunmasına ilişkin bireysel bağll1ık tercihini ortaya koymaktadır '(Simmons, 1979: 69; benim vurgum). Bu konuya yeterince dikkat gösterilmemesi durumunda (bkz. Knowles, 2010: 69), Knowles'ın konumunun, zımni onayın siyasi tartışmaları için olağan bağlam olabileceğine inanmaya devam eder.

2- Zımni rızanın, bazen iznin esasen kasıtlı olduğunu reddetmek için kullanılan siyasi bir bağlam içerisindeki tartışmaları (bakınız, Snare, 1975: 34; Simmons, 1993: 229-230). Ancak, Bölüm VII'de araştırıldığı gibi, Simmons şimdi rızanın esasen kasitlı olduğunu savunuyor (Simmons, 2001: 166, 177). Bu anahtarı, kasitlı olduğuna dair rızayla ilgili mevcut araştırmada daha geniş bir fikir birliğinin göstergesi olarak kabul ediyorum (bkz. Beyleveld ve Brownsword 2007). Her durumda, eleştirdiğim yazarlar, Murphy ve Simmons, öyle olduğunu kabul ediyorlar.

3- Bölüm VII'de, Murphy'nin siyasi yükümlülüğe yönelik zımni bir onay temelli yaklaşımı savunurken farklı bir zımni onay anlayışı benimsediğini görüyoruz.

4- Benzer şekilde, Julian Franklin şöyle iddia ediyor: '[t] "zımni rızası" terimi, rıza ifade etmek için "sessiz" bir eşdeğer anlamına geldiği için yanıltıcıdır' (Franklin, 1996: 421).

5- Ayrıca bakınız Simmons, 1976: 279. Bu erken aşamada, Simmons siyasi yükümlülüklere yönelik zımni rıza yaklaşımını reddetmeye devam etti. Simmons'ın şu anki, konvansiyonel taciz izniyle ilgili siyasi görüşlerine ilişkin mevcut savunmaya dayalı yaklaşımını savunmasıyla birlikte tartışıyorum Bölüm VII. 
6- Ayrıca bakınız, örneğin (Beran, 1987: 8)'deki bu örneğin çeşitli uyarlanmış versiyonları adapte edilmiştir; Horton, 1992: 29 ve Knowles, 2010: 106.

7- 'Özel İlişki' terimi Hart, 1955: 183, 187'den alınmıştır.

8- Bu eserden ve diğer Alman edebiyatından çeviriler yazara aittir (yayınlanmış çeviriler yoktur).

9- Simmons bir keresinde siyasal olmayan metinlerde durmadan ve sessiz kalmanın, (1) durumun doğasını anlamadaki başarısızlıktan (2) uygun işlemlerin anlaşılmamasından kaynaklanmadığı zaman rıza göstermesi gerektiğini veya (3) ne kadar süre karar verilip verilmeyeceğine karar verilmesi gerektiğine dair bir yanlış anlama olduğunu öne sürdü. Ayrıca bkz. '(Simmons, 1979: 81; Simmons 1976: 279). $\mathrm{Bu}$ öneri, sadece herhangi bir sokak satıcısının uygun bir adım atmakta ustaca yetkinliğini güçlendirmekle kalmayacak, aynı zamanda sonucu rıza dilinde de süsleyecektir.

10- Bu bölüm hakkında daha fazla tartışma için bakınız bölüm VIII.

11. Kurgular tanıtıldıktan sonra, sözleşmelerin kişilerin yasal haklarını ve/veya görevlerini değiştirme niyetiyle karşılık gelen eylemleri yapmalarını veya bu tür eylemleri yerine getirme düşüncesiyle hareket etmeleri gerektiği söylenmelidir. Vasiyetnameye ilişkin beyannamelerin, Bölüm V'teki vasiyetname beyanlarının gerçek ve kurgusal ilanlarına sınıflandırılmasını tartışırım. Fuarın bu aşamasında önemli olan nokta, irade süreleri ile özgür eylemler arasındaki ayrımın, her ikisinin de kurgusal olabileceği gerçeğinden taviz vermemesidir. Yasal sonuçların kurgusal bir irade beyanına bağlandığı ve gerçek veya kurgusal olan herhangi bir irade beyanına atıfta bulunulmaması gereken bir karar arasında bir fark vardır. Örneğin, izleyen tarafın neyin uygun olduğuna karar verebileceği konusundaki düşüncelere hitap eden bir karar arasında bir anlaşmanın yasal olarak uygulanabilir olduğu sonucuna varmak için (diğer tarafın gerçekten bağlamayı amaçlamamasına rağmen bir fark vardır. Kendileri) ve vahşi bir hayvanın işgalini tesis etmek için sadece tutuklama ve sahip olma isteği gibi serbest davranışlara itiraz eden bir yargılama vardır. Savigny sayfa 134 'te bu makul beklentileri tartışmaktadır. Ana hatlarıyla belirttiğim beyanname ve irade arasında "doğal ilişki" nin "bozulması" olduğu zaman potansiyel olarak anlamlıdırlar. (Savigny, 1841: 134). Bu yorumlar Savigny' yi Beyleveld ve Brownsword'ün "iddia edilen rızası olan müvekkil tarafından bakıldığında öznellikçi bir yaklaşım" olarak savunduğuna benzer bir şeyi taahhüt eder (Beyleveld ve Brownsword, 2007: 190).

12- Govert Den Hartogh şöyle yazıyor: “Öncelikle başka bir noktaya sahip olan ancak geleneksel olarak bir yükümlülük üstlenmeye yönelik içgüdüyü ifade etmek için alınan bir şeyi yaparsam zımni rıza gösteriyorum. Bir kadeh şarap alarak, şişenin parasını ödemeye izin verebilirim. Bu açık bir rıza hareketi değildir, çünkü hiç kimse şarabı ilk etapta alabileceğimi inkâr etmek istemez, çünkü hoşuma gider. 
'(Den Hartogh, 2002: 64). Bu, tek bir irade beyanı için bir gerekçenin, bir eylemin iki yönlü yasal önemini doğrulamasıyla karıştırır. Yasal hakları ve/veya görevleri değiştirme niyeti, bildirimin zımni olup olmamasına bakmaksızın yasal olmayan bir nedeni olabilir.

13- Reinhard Zimmermann şöyle bildirir: "Zorunlu eylem ve nakil arasındaki Roman ayrımı birçok modern hukuk sisteminde hala korunmaktadır" (Zimmermann, 1990: 271). Örneğin, Alman Medeni Kanunu'nun 433 ve 929'uncu maddelerine bakınız.

14- (1) ve (2)'deki hataya ve (1) ve (6)'daki protestolara açık referanslara bakınız.

15- Bu örnek, Fuller, 1967: 41'den uyarlanmıştır.

16- İki farklı fark, onay beyanlarının gönüllü ve bilinçli niteliği ile ilgilidir. Bazı irade beyanları zorlanabilir veya yanlış şekillenmiş olabilir, ancak bu zorlama ve aldatma onların iptali için zemin sağlamıştır. Aksine, onay beyanları esas olarak isteğe bağlıdır ve yanlış bilgi içermez. Rızanın gönüllü ve bilgilendirilmiş karakteri rıza hakkındaki mevcut literatür tarafından iyi araştırılmıştır (bkz. Beyleveld ve Brownsword, 2007.)

17- Bu durum ve iznin kasıtlı niteliği hakkında daha ayrıntılı bir tartışma için, bkz. Beyleveld ve Brownsword, 2007: 1-3.

18- Bana önerilen bir karşı örnek, cinsel derse rıza gösterme eylemidir. Ancak burada, bir rıza eylemi, artık rıza göstermediği takdirde ve diğerine bildirmek için ahlaki bir yükümlülük yaratır.

19-Aslında bu bölüm, bir sözleşmenin önceden doğacak vekille aynı konumda olacağı durumlarda bile zımni rızanın verildiğini öne sürmektedir ("girmemek, hiçbir şekilde bir fayda sağlayamaz"). Ancak bu öneri, eylemlerin 'bir miktar iyiliği sağlamayı amaçladığı' anlaşılabilirlik ilkesine aykırı olduğu için bunu görmezden geliyorum.

20- Makalenin bu bölümünde amaç, zımni rıza temelli siyasi yükümlülük teorisini değerlendirmektir. Bu nedenle iki tür kısıtlamaya tabidir. Birinci tür kısıtlama, diğer herhangi bir siyasi yükümlülük teorisini değerlendirmeyi amaçlamamasıdır. Özellikle, faydaların elde edilmesinde siyasi yükümlülüğü temel alan teorileri tartışmaz, çünkü bu faydaların elde edilmesi için rızaya gerek yoktur. İkinci tür kısıtlama, , bu rızaya dayalı teorilerin temelini attığı gibi siyasi yükümlülüğün başka bir yönünü tartışmayı amaçlamamasıdır. Bu ikinci kısıtlamanın iki sonucu vardır. Birincisi, dikkatin, insanların devlet komutlarına uymalarının ahlaki yükümlülüğe odaklanmasıdır. Kişilerin (veya vatandaşların daha özel olarak) özgürlüklerini veya yetkilerini belirli şekillerde kullanma (örneğin kendilerini bir aile evinde belirli şekillerde kullanma veya oy kullanma haklarını kullanma) gibi ahlaki bir yükümlülük olduğu iddialarını inceleme çabası yoktur. İkinci bir sonuç, dikkatin, kişilerin ilan edilen genel kurallar biçiminde devlet 
emirlerine uyma ahlak yükümlülüğüne odaklanmasıdır. Kişilerin (veya vatandaşların daha özel olarak) bu formu almayan devlet emirlerine uyma konusunda ahlaki bir yükümlülüğü olduğu iddialarını inceleme girişimi yoktur (bkz. Locke, 2003: 42 ve 87).

21- Ayrıca bakınız, Hobbes, 1998: 451.

22- 'Hürmet'e eşlik eden referans, Locke'un zımni rızaya itirazını yorumlamamda hiçbir rol oynamaz. Hürmet ödemesi, kesinlikle sadece 'sakinlerden ve/veya mülk sahiplerinden kaynaklanmaktadır. Bu nedenle, bir devletin 'topraklarında' gerçekleştirilen tüm eylem sınıfının ahlaki bir sonucu olarak saymak yeterince genel değildir. Ayrıca, korumanın tümü "nedeniyle" olduğu için, zımni rızaya itirazın, Knowles'ın önerdiği gibi, bir ahlaki koruma hakkı varsayımına yol açtığını unutmayın (Knowles, 2010: 110, 133). Korece karşılık veren yasal koruma hakkının belirli bir hak sahibine fayda sağlayacak şekilde yönetilip yönetilmeyeceği ampirik bir konudur. Düzgün bir rıza temelli siyasi yükümlülük teorisinin savunucularının, bunun kanıtı olduğunu göstermeleri gerekmez.

\section{Kaynakça}

Austin, J. (1861). The Province of Jurisprudence Determined. London: Murray

Beale, H, et al. (2002). Contract Law, Portland: Hart.

Bennett, J. G. (1979). "A Note on Locke's Theory of Tacit Consent". The Philosophical Review, 2, 224-234.

Bentham, J. (1977). A Fragment on Government in J. H. Burns and H. L. A. Hart (eds) The Collected Works of Jeremy Bentham. London: Athlone Press.

Beran, H. (1987). The Consent Theory of Political Obligation. London: Croom Helm.

Beyleveld, B. and R. Brownsword. (2007). Consent in the Law. Oxford: Hart.

Franklin, J. H. (1996). “Allegiance and Jurisdiction in Locke's Doctrine of Tacit Consent". Political Theory, 24, 407-422.

Fuller, L. L. (1967). Legal Fictions. Stanford: Stanford University Press.

Gross, W. and W. Söhnlein (eds). (1993). Bürgerliches Recht 1. Wiesbaden: Gabler.

Gursky, K.-H. A. Pfeifer, and W. Wiegand. (2004). J. Von Staudingers Kommentar zum Bürgerlichen Gesetzbuch, Drittes Buch, Sachenrecht, ss. 925-984. Berlin: Sellier-de Gruyter.

Hart, H. L. A. (1955). “Are There Any Natural Rights?”. The Philosophical Review, 64:2, 175-191.

Hart, H. L. A. (1994). The Concept of Law. Oxford: Clarendon Press.

Den Hartogh, G. (2002). Mutual Expectations: A Conventionalist Theory of Law, The Hague: Kluwer.

Hobbes, T. (1998). Leviathan. Cambridge: Cambridge University Press. 
Horton, J. (1992). Political Obligation. Basingstok: Macmillan Press.

Hume, D. (1875). Of the Original Contract in T. H. Green and T. H. Grose (eds) The Philosophical Works of David Hume, Longmans. III. London: Longmans.

Knowles, D. (2010). Political Obligation. London: Routledge.

Locke, J. (2003). Second Treatise on Government. New Haven: Yale University Press.

Martinek, M. (ed). (2004). J. Von Staudingers Kommentar zum Bürgerlichen Gesetzbuch, Zweites Buch, Recht der Schuldverhältnisse, ss. 433-487. Berlin: Sellier - de Gruyter.

Maurer, J. (2001). Die Prinzipien der Abstraktion, Kausalität und Trennung, insbesondere bei Verfügungen. Frankfurt am Main: Peter Lang.

Murphy, M. C. (1994). Hobbes on Tacit Covenants. Hobbes Studies 7, 69-94.

Murphy, M. C. (2006). Natural Law in Jurisprudence and Politics. Cambridge: Cambridge University Press.

Plamenatz, J. P. (1968). Consent, Freedom and Political Obligation. Oxford: Oxford University Press.

Riesenfeld, S. 1989. "The Influence of German Legal Theory on American Law”. American Journal of Comparative Law, 37, 1-7.

Russell, R. (1986). Locke on Express and Tacit Consent. Political Theory 14, 291-306.

Von Savigny, F. K. (1841). System des heutigen römischen Rechts Band 3. Berlin: Veit und Comp.

Simmons, A. J. (1976). Tacit Consent and Political Obligation. Philosophy and Public Affairs 5, 274-291.

Simmons, A. J. (1979). Moral Principles and Political Obligations. Princeton: Princeton University Press.

Simmons, A. J. (1993). On the Edge Of Anarchy. Princeton: Princeton University Press.

Simmons, A. J. (2001). Justification and legitimacy. Cambridge: Cambridge University Press.

Simmons, A. J. (2005). "Consent Theory for Libertarians". Social and Philosophy and Policy, 22, 330-356.

Snare, F. (1975). "Consent and Conventional Acts in John Locke". Journal of the History of Philosophy, 13, 27-36.

Zimmermann, R. (1990). The Law of Obligations. Cape Town: Juta 